Article

\title{
AGB Estimation in a Tropical Mountain Forest (TMF) by Means of RGB and Multispectral Images Using an Unmanned Aerial Vehicle (UAV)
}

\author{
Víctor González-Jaramillo ${ }^{1,2, *(\mathbb{D}}$, Andreas Fries ${ }^{1}\left(\mathbb{D}\right.$ and Jörg Bendix ${ }^{2}(\mathbb{C})$ \\ 1 Departamento de Geología y Minas e Ingeniería Civil (DGMIC), Grupo de trabajo de Hidrología y \\ Climatología, Universidad Técnica Particular de Loja, San Cayetano Alto, Loja 1101608, Ecuador; \\ aefries@utpl.edu.ec \\ 2 Laboratory for Climatology and Remote Sensing (LCRS), Faculty of Geography, University of Marburg, \\ Deutschhausstr. 10, 35032 Marburg, Germany; bendix@staff.uni-marburg.de \\ * Correspondence: vhgonzalez@utpl.edu.ec; Tel.: +593-073701444
}

Received: 2 May 2019; Accepted: 7 June 2019; Published: 14 June 2019

\begin{abstract}
The present investigation evaluates the accuracy of estimating above-ground biomass (AGB) by means of two different sensors installed onboard an unmanned aerial vehicle (UAV) platform (DJI Inspire I) because the high costs of very high-resolution imagery provided by satellites or light detection and ranging (LiDAR) sensors often impede AGB estimation and the determination of other vegetation parameters. The sensors utilized included an RGB camera (ZENMUSE X3) and a multispectral camera (Parrot Sequoia), whose images were used for AGB estimation in a natural tropical mountain forest (TMF) in Southern Ecuador. The total area covered by the sensors included 80 ha at lower elevations characterized by a fast-changing topography and different vegetation covers. From the total area, a core study site of 24 ha was selected for AGB calculation, applying two different methods. The first method used the RGB images and applied the structure for motion (SfM) process to generate point clouds for a subsequent individual tree classification. Per the classification at tree level, tree height $(\mathrm{H})$ and diameter at breast height $(\mathrm{DBH})$ could be determined, which are necessary input parameters to calculate AGB $\left(\mathrm{Mg} \mathrm{ha}^{-1}\right)$ by means of a specific allometric equation for wet forests. The second method used the multispectral images to calculate the normalized difference vegetation index (NDVI), which is the basis for AGB estimation applying an equation for tropical evergreen forests. The obtained results were validated against a previous AGB estimation for the same area using LiDAR data. The study found two major results: (i) The NDVI-based AGB estimates obtained by multispectral drone imagery were less accurate due to the saturation effect in dense tropical forests, (ii) the photogrammetric approach using RGB images provided reliable AGB estimates comparable to expensive LiDAR surveys $\left(R^{2}: 0.85\right)$. However, the latter is only possible if an auxiliary digital terrain model (DTM) in very high resolution is available because in dense natural forests the terrain surface (DTM) is hardly detectable by passive sensors due to the canopy layer, which impedes ground detection.
\end{abstract}

Keywords: forest AGB; UAV; RGB data; multispectral data

\section{Introduction}

Accurate information about forest cover, land use and above-ground biomass (AGB) are critical parameters for many environmental studies as well as for conservation initiatives concerning the mitigation of global warming, such as REDD+ (Reducing emissions from deforestation and forest degradation and the role of conservation, sustainable management of forests and enhancement of forest carbon stocks in developing countries) [1,2]. By means of such data and their temporal development, 
the most vulnerable regions can be determined, and areas which deserve protection can be identified. In particular, natural forest cover is of utmost concern because it stores and sequesters large amounts of atmospheric carbon (nearly 30\% of the cumulative anthropogenic emissions [3-6]. However, the high deforestation rates observed in tropical countries complicate mitigation actions and efforts. Furthermore, affected areas become sources of additional greenhouse gas (GHG) emissions [7,8], amplifying the global change [9].

The highest deforestation rates in South America were estimated in Ecuador [7,10], where specifically the tropical mountain forest (TMF) has been and is still affected for several reasons, such as population growth, economic crises, and planning processes [11,12]. During the last few decades, human activities changed the natural vegetation cover [13,14], mostly by slash-and-burn activities to produce pasture and agricultural land [15]. Therefore, carbon storage or AGB has changed, caused additionally by the extraction of desirable timber species, which is why natural forest cover is often disturbed or fragmented [16,17]. The AGB stock mostly consists of wood and branches of the different species $(70 \%$ to $90 \%$ of AGB) $[18,19]$ in which large or dominant trees ( 25-30 m) contain more than $75 \%$ of total carbon stored [20]. Therefore, the determination of actual forest cover and AGB in high resolution is necessary to provide accurate data about existing carbon storage, which is the basis for future scenarios of potential C-sequestration or emission under environmental changes in the future [21].

To fulfill this requirement, information in very high resolution $(\mathrm{cm})$ is necessary, which is especially challenging in TMF due to the high biodiversity, difficulties in access, and the fast-changing forest structure [22,23]. Remote sensing platforms provide a solution [24-27] because this technology offers information in very high resolutions and is independent of topographic conditions [28,29]. The best remote sensing alternative is "light detection and ranging" (LiDAR) [30], a laser technology with an extremely high resolution, which provides 3D data suitable for a wide range of applications, including AGB estimation [31-33]. However, this technology is expensive and generally inaccessible for developing countries [8], requiring that other more cost-effective platforms must be considered.

Optical satellite data in very high spatial resolution can also provide the required information (e.g., platforms: WorldView, GeoEye, IKONOS, QuickBird, Pleiades) [34], but these sensors are sensitive to weather conditions (e.g., cloudiness [35]), besides the elevated costs for very high-resolution image acquisition [36]. Nonetheless, coarse to moderate resolution satellite images facilitate temporal information and historical data, at least for the last few decades (NOAA-AVHRR, Aster, MODIS or Landsat) [37-39]. This information can be used for forest classification, forest cover determination, and deforestation rate estimation $[25,40]$ but hardly for accurate local AGB calculation and natural TMF monitoring due to high cloudiness and the fast-changing topography in tropical high mountains [41].

A third, more accessible technology is drones or unmanned aerial vehicles (UAV), which allow for the detection of surface data in very high spatial and temporal resolution [42-44]. The available sensors can provide 3D and multispectral information $[4,45]$, which permit AGB estimation as well as ecosystem monitoring at small scale [28]. However, the range of UAVs is limited due to their battery capacity. At the same time, the image resolution as well as surface coverage depend on UAV flight height (ground sample distance-GSD) [2]. Nonetheless, UAVs have demonstrated their potential to complement or fill the gaps in more expensive surveys, like LiDAR [45,46]. As Weber and Lerch [47] stated, the accuracy level of photogrammetric products generated by means of UAV data is acceptable for relatively small areas where high resolution information is required (centimeter level).

According to our knowledge, AGB estimation by means of UAV data has not been applied in remote natural TMF. Thus, this study applies two different methods for AGB estimation in a remote TMF ecosystem in Southern Ecuador, using a UAV (DJI Inspire 1) [48] equipped with an RGB camera and a multispectral senor. On the one hand, the RGB data were utilized to obtain 3D point-clouds [45] from which a digital terrain model (DTM), a digital surface model (DSM), as well as a canopy height model (CHM) were generated and an individual tree classification executed. By means of the individual tree parameters, the specific allometric equation for tropical wet forest proposed by Chave et al. [49] was 
applied to estimate the AGB $\left(\mathrm{Mg} \mathrm{ha}^{-1}\right)$. On the other hand, the Red and NIR bands of the multispectral sensor were used to calculate the normalized difference vegetation index (NDVI), which is the basis for AGB estimation applying the equation for evergreen forest proposed by Das and Singh [50]. Finally, the results of the two methods were evaluated comparing the obtained UAV AGB with an independent reference AGB dataset derived from LiDAR data for the same area [8].

\section{Materials and Methods}

\subsection{Study Area}

The study was executed in a natural TMF in the eastern escarpment of the South Ecuadorian Andes, specifically inside the San Francisco watershed, where the research station "Estación Científica San Francisco" (ECSF: Lat. $3^{\circ} 58^{\prime} 18^{\prime \prime} \mathrm{S}$, long. $79^{\circ} 4^{\prime} 45^{\prime \prime} \mathrm{W}$ ) is located. Altitudes range from $1600 \mathrm{~m}$ above sea level at the river outlet to $3200 \mathrm{~m}$ above sea level at the highest mountain peaks (Figure 1). The San Francisco watershed has an extension of $\sim 85 \mathrm{~km}^{2}$ and is a hotspot for biodiversity due to its extraordinary variety of flora and fauna [51,52]. The natural TMF covers the slopes from the valley bottom up to the tree line ( $2700 \mathrm{~m}$ above sea level) [12,53] and can be divided into lower slope (ravine) forest and upper slope (ridge) forest [54]. This natural forest structure is related to topography, climatic conditions, and prevailing soil types $[55,56]$. The ravine forest is characterized by lower stem density but higher basal areas (diameters) and canopy heights compared to the ridge forest, which also contains fewer tree species [8,22]. The selected study site has an area of 80 ha and is located at lower elevations (1700 $\mathrm{m}$ above sea level to $2200 \mathrm{~m}$ above sea level), including ravine and ridge forest areas (Figure 1).
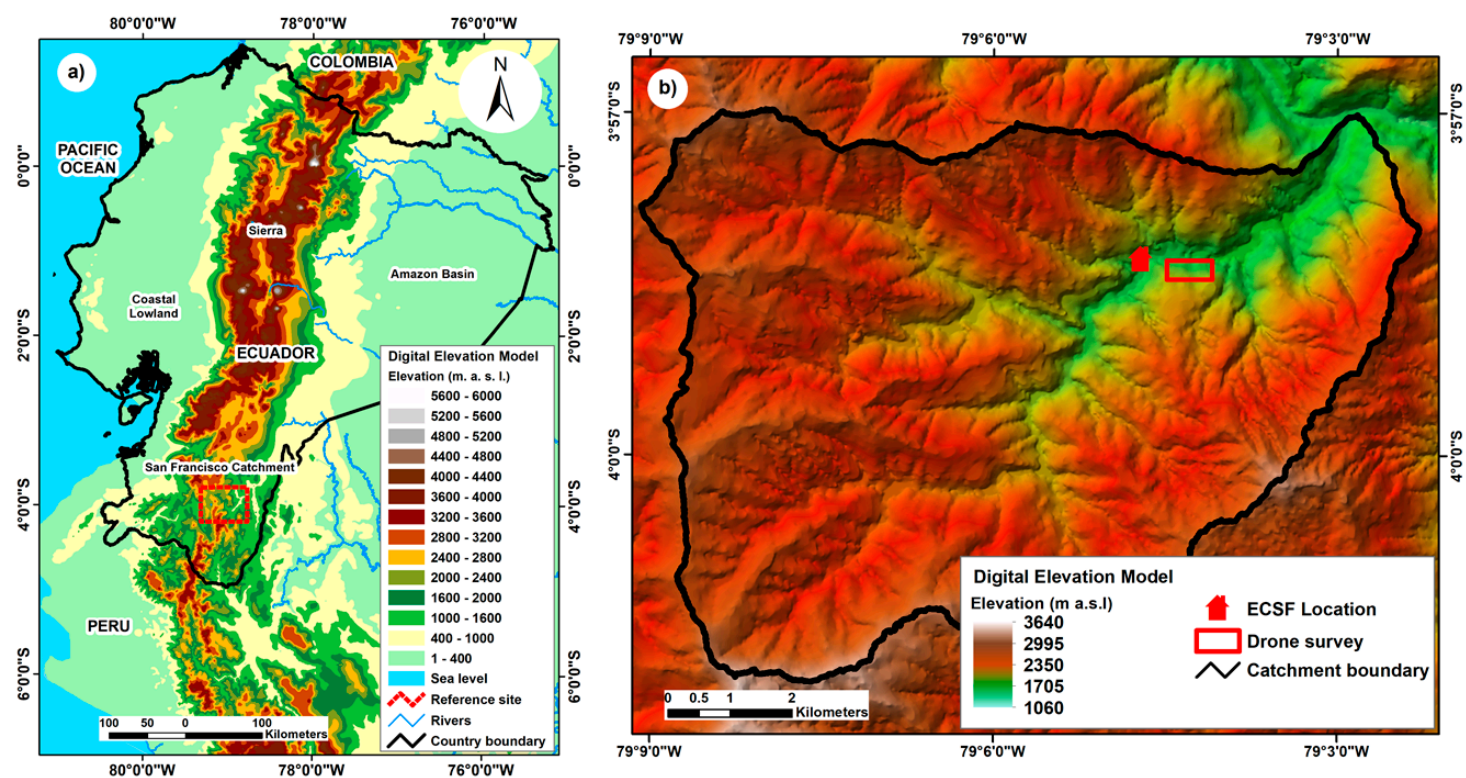

Figure 1. (a) Digital elevation model (DEM) of Ecuador, and (b) DEM of the San Francisco catchment including the study area.

The climate within the study area is per-humid with marked altitudinal gradients in air temperature, air humidity [57,58], cloudiness [59], rainfall [60], and wind conditions [56]. Mean annual air temperature ranges from $19.4{ }^{\circ} \mathrm{C}$ at the valley bottom to $9.4^{\circ} \mathrm{C}$ at the mountain tops, whereas average relative humidity varies between $70 \%$ at the valley bottom and at open sites to nearly $100 \%$ at the mountain ridges and inside the TMF. Precipitation shows a clear annual cycle with a main rainy season in austral winter (between May and September) and a relative dry season in austral summer (between November and February). Wind direction is predominately from the east due to the tropical easterlies, reaching average monthly velocities up to $15.5 \mathrm{~m} \mathrm{~s}^{-1}$ at the ridges in austral winter [61]. 


\subsection{Equipment}

To estimate the AGB in the natural TMF, the UAV DJI Inspire 1 [48] was used, which was equipped with an RGB camera (ZENMUSE X3) and a multispectral camera (Parrot Sequoia) [62].

\subsubsection{DJI Inspire 1}

The UAV DJI Inspire 1 is a multi-rotor drone with 4 electric motors (quadcopter, Figure 2) that includes a remote controller that operates up to $2 \mathrm{~km}$ (radio) under unobstructed environmental and undisturbed meteorological conditions [48]. The maximum speed of the drone is $22 \mathrm{~m} \mathrm{~s}^{-1}$, and its maximum operation altitude is $4500 \mathrm{~m}$ above sea level. Factory built, the DJI Inspire 1 is equipped with the RGB ZENMUSE X3 camera with a resolution of 12 megapixels, which also includes an integrated gimbal system that provides stability and avoids distortion and blurring. The flight time varies with respect to payload, altitude above sea level, and weather conditions (mainly wind speed) but generally lies between 12-18 min. By considering the additional weight of a multispectral sensor and its external battery (approximately $250 \mathrm{~g}$ ), an average flight time of about $10 \mathrm{~min}$ could be achieved for the mountainous environment in the study area.

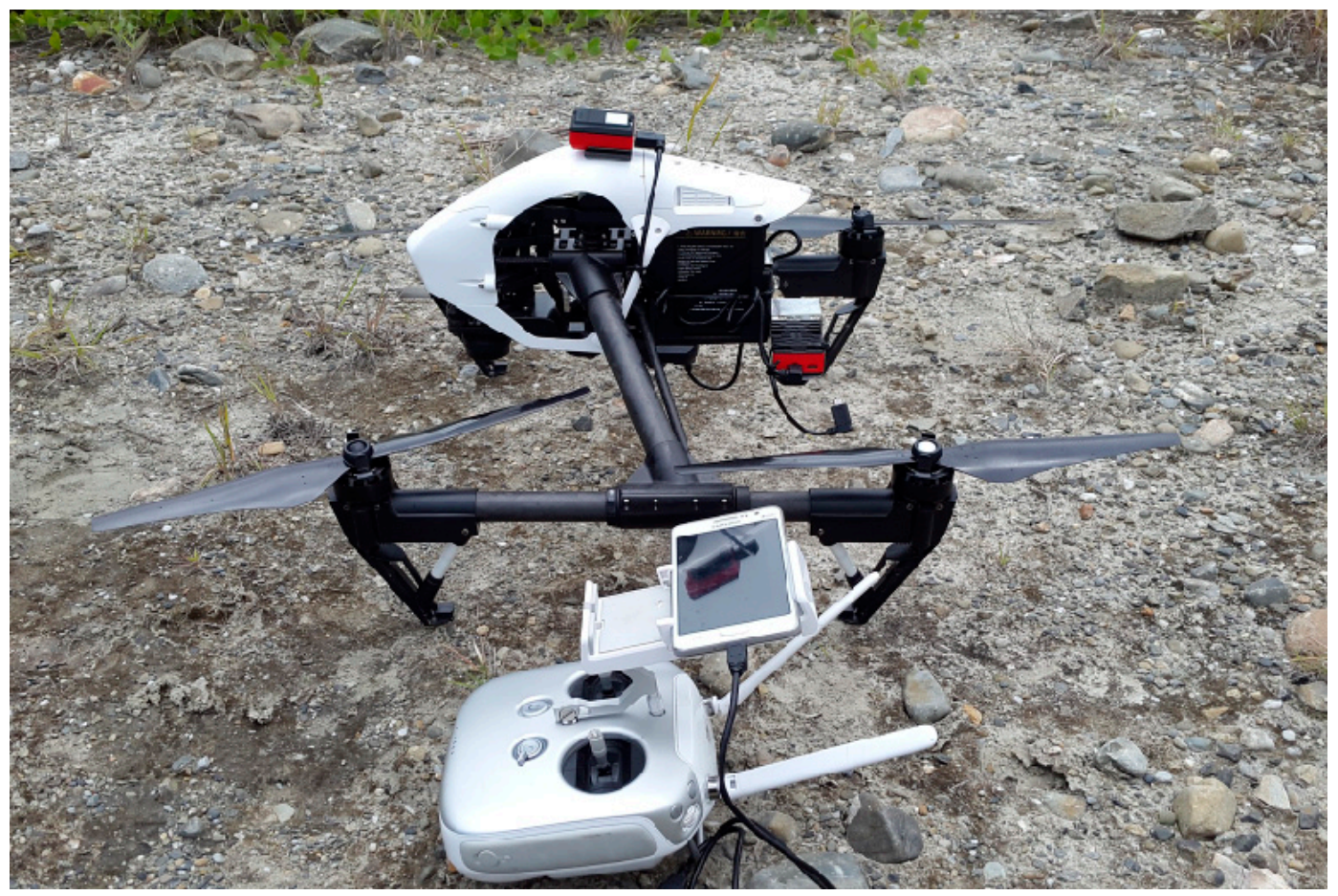

Figure 2. Unmanned aerial vehicle (UAV) DJI Inspire 1, equipped with the RGB camera ZENMUSE X3 and the multi-spectral camera Parrot Sequoia.

\subsubsection{Parrot Sequoia}

The Parrot Sequoia camera is a multispectral sensor [62] that allows for the capture of imagery at 4 specific bands within the visible and infrared electromagnetic spectrum: Green (550 nm), red (660 $\mathrm{nm})$, red edge $(735 \mathrm{~nm})$, and near infrared $(790 \mathrm{~nm})$. Furthermore, the camera includes a sunshine module that automatically calibrates the received images to compensate for the variability in sunlight conditions during flight as well as during different campaigns [63]. The specific bands of the Parrot Sequoia camera are similar to multispectral sensors onboard Landsat and NOAA-AVHRR satellites, allowing for comparable investigations to be conducted [62]. 


\section{Methodology}

\subsection{Flight Planning and Data Acquisition}

Depending on the size of study area, specific characteristics of the employed UAV must be considered (especially payload and resulting flight time) to determine the area covered by one single flight as well as the number of flights necessary to cover the whole area of interest. For the present research, a core site of 24 ha was selected, located at lower elevations in the San Francisco catchment, including parts of the valley bottom (river), side valleys, and ridges covered by natural TMF in which small gaps of natural succession (ancient landslides, grassland, and scrubs) are also present (Figure 3). To ensure complete coverage of the core site, the limits for data acquisition (vertical photographs) were extended at all borders (total area of coverage: $80 \mathrm{ha}$ ).

The flight characteristics were configured by means of the free software Precision Flight [64], an application that runs on an Android device that afterwards automatically executes the planned survey. The flight path was designed in an east-west direction with a nominal speed of $9 \mathrm{~m} \mathrm{~s}^{-1}$ to cover the whole area ( $80 \mathrm{ha}$ ) by two flights of approximately $10 \mathrm{~min}$. The data were taken at a flight height of 300 $\mathrm{m}$ above the starting point with $90 \%$ side and forward overlap of the images, as recommended by the Pix4D documentation for locations with fast-changing topography and forests with dense canopies, to obtain enough points for individual image matching [65].

To improve the accuracy of the obtained images (coordinates $\mathrm{X}, \mathrm{Y}$ and $\mathrm{Z}$ ), ground control points (GCPs, Figure 3) were set within the area of coverage before executing the flights $[28,66]$. A minimum of 3 GCPs are necessary to ensure reliable image accuracy, but five to 10 GCPs are more suitable, particularly for larger areas [67]. It has been proven that a higher number of GCPs do not improve the final product significantly, nor do they improve the image accuracy [68], so for this reason six GCPs were set for the present study. The GCPs were located at flat open sites inside the total area ( $80 \mathrm{ha})$ to guarantee easy detection within the images. Therefore, dense canopies, steep slopes, and positions too close to the borders were avoided because the local topography as well as the camera position modifies the nadir angles of the different objects [29]. The exact geographical position of the GCPs (Figure 3) were determined using a GPS Trimble R6 system. Furthermore, the multispectral camera needs a radiometric calibration target to guarantee reliable values for each individual spectral band. Therefore, an AirInov target, specifically designed for the Parrot Sequoia camera, was used to calibrate the bands before flight execution. More information about the target and its application can be found in [63].

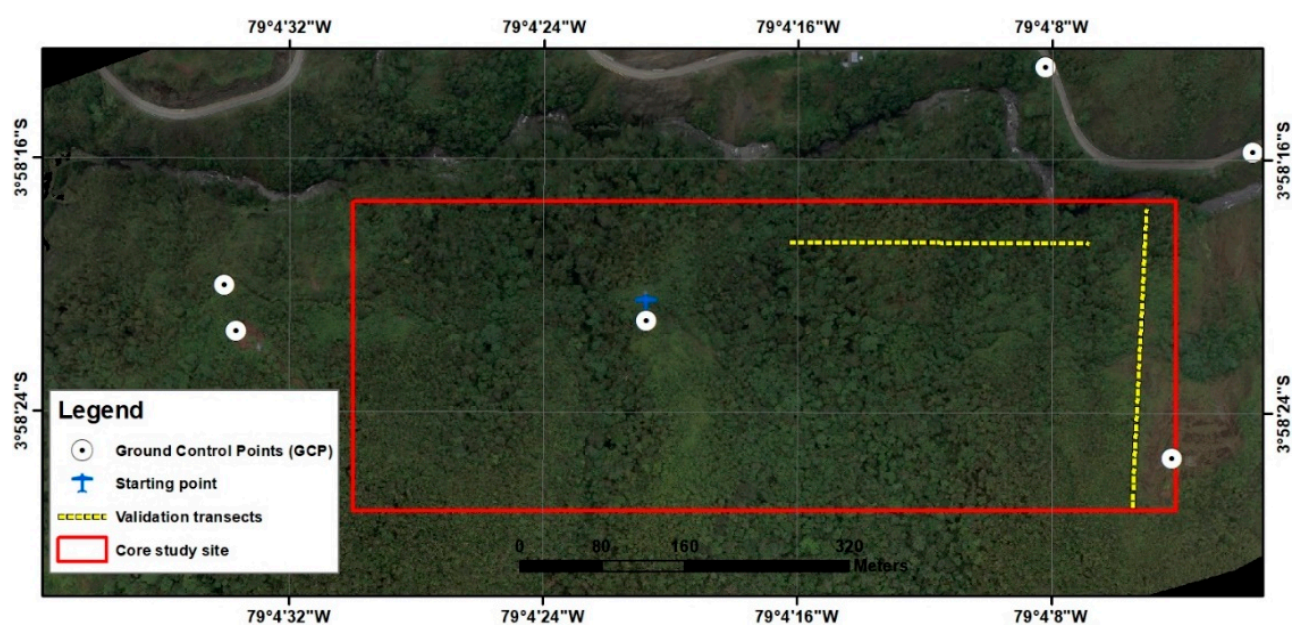

Figure 3. Drone-based orthophoto of the selected study area, including the starting point, ground control points (GCP), and validation transects (yellow) inside the core area (rectangle). 
The UAV flights were executed under sunny weather conditions during 26 April 2018, before the main rainy season started. During the survey, 132 RGB images and 230 multispectral images were obtained, which resulted in a total raw data size of 8 GB.

\subsection{Data Processing}

The data processing chain for AGB estimation by means of the RGB and multispectral images is shown in Figure 4. Both image types were analyzed independently.

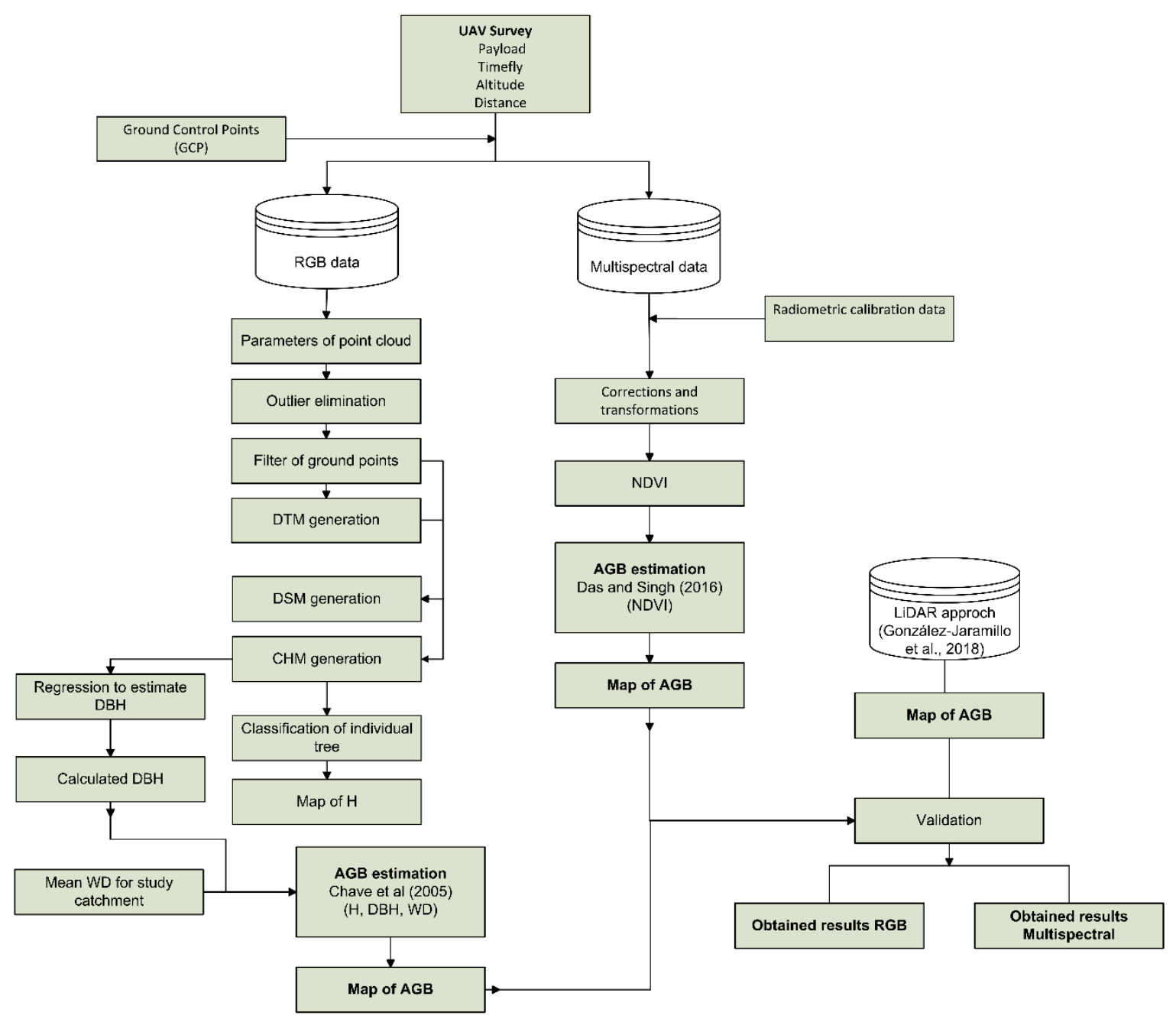

Figure 4. Processing chain to estimate above-ground biomass AGB ( $\mathrm{Mg} \mathrm{ha}^{-1}$ ) using RGB (left) and multispectral imagery (right).

\subsubsection{AGB Estimation by Means of RGB Data-Use of Photogrammetry}

Allometric equations are widely used for AGB estimation [69-71] because they include forest structure parameters, such as tree height $(\mathrm{H})$, tree diameter at breast height $(\mathrm{DBH})$, and wood density (WD). The required information at tree level can be obtained by remote sensed data ( $\mathrm{H}$ and $\mathrm{DBH})$ and non-destructive field measurements $(\mathrm{H}, \mathrm{DBH}$, and WD), which do not harm the ecosystem [8,72]. For individual $\mathrm{H}$ detection, 3D data (point clouds) are required, which can be derived from expensive LiDAR surveys [73] but also from RGB data when applying computational photogrammetric techniques [1,74].

To obtain the 3D data, first, the raw data of the ZENMUSE X3 camera were checked and all images at the beginning and at the end of each individual flight eliminated because these images do not comply with the established flight characteristics (flight height, image overlap, and pixel resolution). 
The revised dataset included 132 images, which were used to generate an orthophoto (Figure 3) and a point cloud for the whole study area (Figure 5). The remaining images were processed using the Pix4D software [65], which uses the structure from motion (SfM) process [75]. This process applies the principles of traditional stereoscopic photogrammetry in which the horizontal and vertical position of specific geometrical features are determined using several images of the same object taken under different viewing angles [74]. This can be done by means of a series of RGB images with a side and forward overlap of between $60 \%$ and $90 \%$. For the present study, an overlap of $90 \%$ was fixed to avoid mismatches during the overlap process of the images. Furthermore, the fast-changing topography and forest structure in the study area requires a higher overlap to obtain enough points for image matching [65].

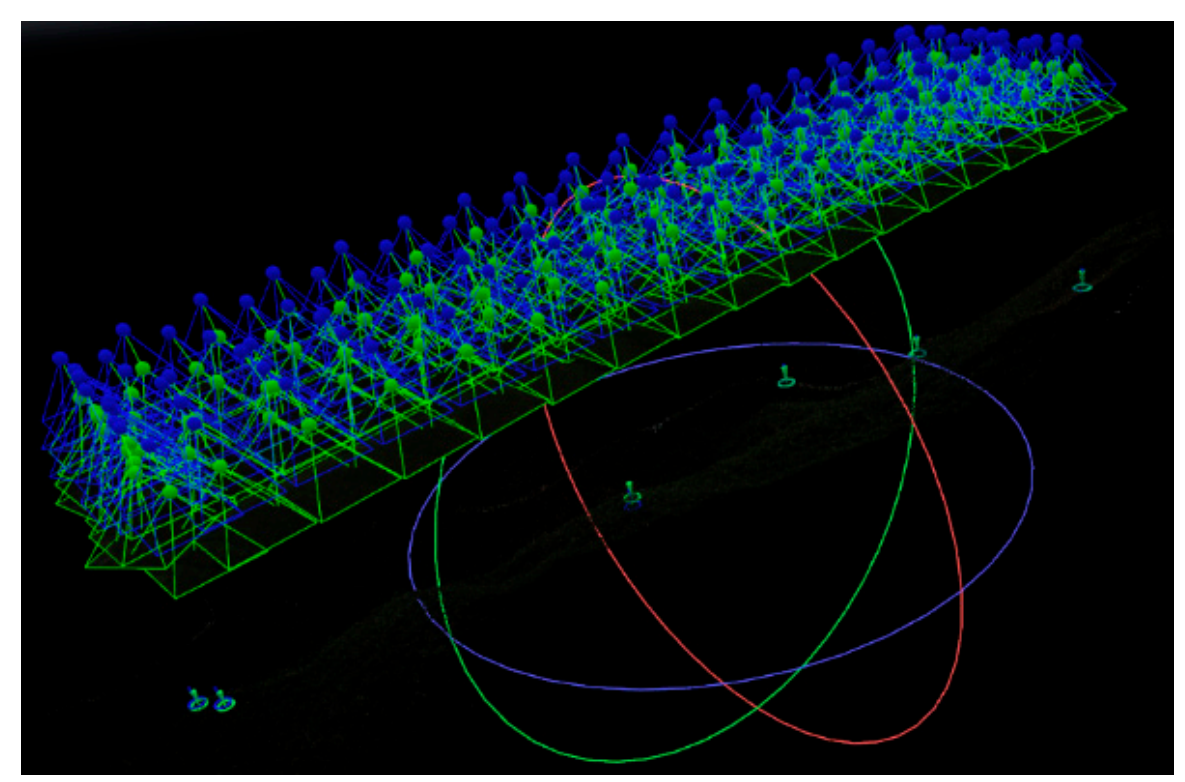

Figure 5. Data processing of the 132 RGB images in Pix4D (SfM), where dots in blue and green represent the individual photos and their overlap. GCPs are shown below.

As Aasen et al. [28] stated, the SfM processing provides a high geometric fidelity if the obtained/captured images contain the exact geographical position and orientation of the spectral sensor. These conditions are given for the present study because sensor orientation is implemented in the ZENMUSE X3 camera (orientation), and the DJI Inspire 1 drone includes an on-board inertial measurement unit (IMU) sensor receiving GNSS signals (geographical position) [48]. As mentioned before, to improve the accuracy of the resulting images, six GCPs were set within the study area, which guarantees reliable image accuracy [76]. The location of the GCPs was introduced in the photogrammetric process, which identifies the specific GCP in each individual image and merges the image accordingly. The six GCPs were identified in 120 images, which is why a high geometric fidelity of the resulting information can be assumed [28,67].

In general, the workflow of the SfM approach consists of three major steps: (i) Feature extraction, (ii) feature matching, and (iii) reconstruction. Most of the processing time is needed for feature matching [76]. The software overlaps all available images and generates 3D-point clouds by means of the different angle views of the individual images [65,76]. Therefore, sufficient GCPs are necessary, especially in primary forests, to obtain reliable image matching [66]. The obtained point cloud was reduced to the core study site, located in the center of the investigation area. The Pix4D software also generates an orthophoto whose resolution depends on flight altitude (here: $300 \mathrm{~m}$ above ground). The programmed flight characteristics resulted in a pixel size (GSD) of about $25 \mathrm{~cm}$ for the orthophoto (see Figure 3) and the 3D point cloud (Figure 5). 
To obtain $\mathrm{H}$ and $\mathrm{DBH}$ estimates for individual trees, the 3D point cloud was processed according to the method presented by González-Jaramillo et al. [8]. From the 3D point cloud, a digital terrain model (DTM) and a digital surface model (DSM) were created, in which the DTM model can be interchanged with any other DTM in very high resolution available for the study area [77]. The utilized software (Fusion 3.7) [78] subtracts the DTM from the DSM to obtain a canopy height model (CHM), which displays the difference between the ground (terrain, bare-earth points) and the highest elevation returns for each GSD [79]. In this case, the CHM depicts the vegetation height while the Canopy Maxima method was also applied within a variable-size evaluation window (here: $3 \times 3$ ) [80] to estimate individual $\mathrm{H}$ of dominant trees, which represent $70 \%$ to $90 \%$ of the total AGB of a forest stand $[18,19]$. For this study, only dominant trees higher than $5 \mathrm{~m}$ with a DBH greater than $10 \mathrm{~cm}$ were considered to calculate the AGB, as Gianico et al. [79] recommended.

The $\mathrm{H}$ of the individual trees detected was used to calculate the DBH based on the height-diameter relationship equation established by González-Jaramillo et al. [8] for the same study area (Equation (1)),

$$
\mathrm{DBH}=\mathrm{e}^{\left(\frac{\operatorname{Ln}(\mathrm{H})-0.85}{0.56}\right)}
$$

where $D B H$ is the diameter at breast height in $\mathrm{cm}$, and $H$ is the estimated height of the tree $(\mathrm{m})$, obtained from the point cloud.

To estimate the AGB $\left(\mathrm{Mg} \mathrm{ha}^{-1}\right)$, mean WD from a previous investigation was used, which was obtained by means of field measurements taken in the study area $\left(0.59 \mathrm{~g} \mathrm{~cm}^{-3}\right)$ [81]. The applied AGB equation at tree level corresponds to Chave et al. [49], who suggested a specific equation for tropical wet forest, which can be written as follows (Equation (2)),

$$
\mathrm{AGB}_{\text {tree }}=\exp \left(-2.557+0.940 \times \ln \left(\mathrm{WD} * \mathrm{D}^{2} * \mathrm{H}\right)\right)=0.0776 \times\left(\mathrm{WD} * \mathrm{D}^{2} * \mathrm{H}\right)^{0.940}
$$

where $A G B_{\text {tree }}$ corresponds to the AGB of a specific tree $(\mathrm{Mg}), W D$ represents the wood density average $\left(\mathrm{gr} \mathrm{cm}^{-3}\right), H$ is the obtained height of each detected tree $(\mathrm{m})$ and $D$ is the estimated DBH $(\mathrm{cm})$ obtained by means of Equation (1). The product applying Equation (2) is the AGB per individual tree. Finally, a grid layer with a 1 ha $\times 1$ ha resolution was overlaid to determine AGB per hectare, where all individual tree AGB was added up for each grid cell [8].

\subsubsection{AGB Estimation Using Multispectral Data}

To estimate AGB by means of the multispectral data obtained from the Parrot Sequoia camera, the equation proposed by Das and Singh [50] was applied. They presented a specific equation for different tropical forest types. The selected equation corresponds to tropical evergreen forest, which is comparable to the forest type presented in the study area. The raw data with a spatial resolution of $25 \mathrm{~cm}$ (multispectral imagery) were processed using the Pix4D software [65] which allows radiometric and geometric corrections of each spectral band. As mentioned before, the radiometric calibration was done using an AirInov target [63] before executing the flights. The specific albedo values were provided by the manufacturer [62], which allowed for the correction of the reflectivity values, ranging between 0 and 100 .

To distinguish between forest, bare soil, and shrubs in the corrected images, first, a false color composite was generated. Therefore, the spectral bands NIR, RED, and GREEN were used [82], which highlight areas with vegetation in red, whereas other ground covers are shown in a different color. The false color composite was the basis for a non-supervised classification, using the Iso Cluster Unsupervised Classification tool available in ArcGis 10.5.1. [83,84]. This tool evaluates the whole dataset and classifies the vegetation into different categories (here: Herbs/bare soil, scrubland, and forest).

Then, the normalized difference vegetation index (NDVI) [85] was calculated, which expresses the vigorousness of the vegetation. The NDVI is directly related to the photosynthetic capacity and 
therefore to the energy absorption of the vegetation. Its magnitude ranges between -1 and 1 , in which negative values indicate water bodies, values near 0 bare soils, and positive values vegetation cover [86]. The NDVI is determined by the ratio of the NIR band (near infrared, $790 \mathrm{~nm}$ ) and the RED band (red, $660 \mathrm{~nm}$ ), expressed in Equation (3),

$$
N D V I=\frac{N I R-R E D}{N I R+R E D}
$$

where NDVI is the normalized difference vegetation index, NIR = near-infrared band, and $R E D=$ red spectral band.

After the NDVI calculation, a regular grid mask of 1 hectare was overlaid, and all $25 \mathrm{~cm}$ pixels within a grid averaged to obtain a mean NDVI value per hectare. Finally, the equation for evergreen forest proposed by Das and Singh [50] was applied to calculate the AGB ( $\left.\mathrm{Mg} \mathrm{ha}^{-1}\right)$, which can be written as follows,

$$
A G B=324.2 \times N D V I_{\text {mean }}+14.18
$$

where $A G B$ is the above-ground biomass $\left(\mathrm{Mg} \mathrm{ha}^{-1}\right)$, and $N D V I_{m e a n}$ is the normalized difference vegetation index, averaged for 1 ha.

\subsection{Validation of the RGB and Multispectral AGB Estimations}

The two different techniques for AGB estimation (RGB and multispectral data) using a UAV were validated by means of an independent AGB dataset $\left(\mathrm{Mg} \mathrm{ha}^{-1}\right)$ derived from LiDAR data. The LiDAR survey was executed in the same study area in 2012, using a Leica Geosystem ALS-50-II CM laser scanner installed onboard a Eurocopter AS350B2 Ecuriel Helicopter. The resulting point cloud density was at least 10 pulses per $1 \mathrm{~m}^{2}$ [31], from which a DTM, DSM, and CHM model in a $25 \mathrm{~cm} \times 25 \mathrm{~cm}$ resolution was generated, and the AGB $\left(\mathrm{Mg} \mathrm{ha}^{-1}\right)$ calculated applying an allometric equation [49]. For more details about the LiDAR-AGB calculation, please refer to González-Jaramillo et al. [8].

The RGB model executed in this study is similar to the LiDAR approach [8], although the RGB camera is a passive sensor, whereas the LiDAR laser scanner an active sensor. Therefore, the generated DTM, DSM, CHM and individual tree parameters obtained from the RGB data were compared to the reference data from LiDAR. The multispectral model is different because the AGB $\left(\mathrm{Mg} \mathrm{ha}^{-1}\right)$ is directly calculated by means of the equation for tropical evergreen forests proposed by Das and Singh [50], which is why only the resultant AGB values were compared to the reference LiDAR-AGB.

The accuracy of the obtained results, RGB or multispectral vs. LiDAR, were determined by means of the coefficient of determination $\left(R^{2}\right)$ and the root mean square error (RMSE) $[46,87]$. The equation for $\mathrm{R}^{2}$ (Equation (5)) and RMSE (Equation (6)) are written as follows,

$$
\begin{gathered}
R^{2}=\frac{\sum_{i=1}^{n}\left(x_{i}-\bar{x}\right)^{2}\left(y_{i}-\bar{y}\right)^{2}}{\sum_{i=1}^{n}\left(x_{i}-\bar{x}\right)^{2} \sum_{i=1}^{n}\left(y_{i}-\bar{y}\right)^{2}} \\
R M S E=\sqrt{\frac{\sum_{i=1}^{n}\left(x_{i}-y_{i}\right)^{2}}{n}}
\end{gathered}
$$

where $x_{i}$ and $y_{i}$ are the estimated and measured values, $\bar{x}$ and $\bar{y}$ are the average estimated and measured values, and $n$ is the total number of existing values with respect to the compared parameters.

\section{Results}

\subsection{AGB Results by Means of RGB Data}

By executing the explained photogrammetric processes for the RGB data, an orthophoto (Figure 3) and a point cloud image were obtained (Figure 5). The orthophoto was used simply for supervision, while from the point cloud, the horizontal and vertical structure of the TMF at tree level was determined. 
The point cloud image had an average density of 30 points $/ \mathrm{m}^{2}$ for the total zone ( $\left.80 \mathrm{ha}\right)$, but zones with no information were also present, especially near the borders of the flight domain, for which reason a core area (24 ha) was established to avoid gaps in the information. Furthermore, due to the dense canopies and the fast-changing topography in the core area, which impede the determination of bare earth points by means of images of the RGB information, the high resolution DTM $(25 \mathrm{~cm} \times 25 \mathrm{~cm})$ generated from the LiDAR survey (2012) was used to generate the CHM. As Karpina et al. [77] stated, this interchange is practicable because passive remote sensors cannot detect the terrain surface under dense canopy layers. Therefore, to generate the CHM, the ancillary LiDAR-DTM was subtracted from the RGB-DSM. Then, the Canopy Maxima tool of FUSION 3.7 was executed to detect the local maxima in the $\mathrm{CHM}$, which represents the $\mathrm{H}$ of individual trees and their location. A total of 7075 dominant trees were detected (Figure 6a), and, by means of Equation (1), their individual DBH calculated. To estimate AGB $\left(\mathrm{Mg} \mathrm{ha}^{-1}\right)$, a grid mask of 1 ha $\times 1$ ha was overlaid and all AGB values of the individual trees within a grid cell were added up. The resulting AGB map of the core area is shown in Figure $6 \mathrm{~b}$.

a)

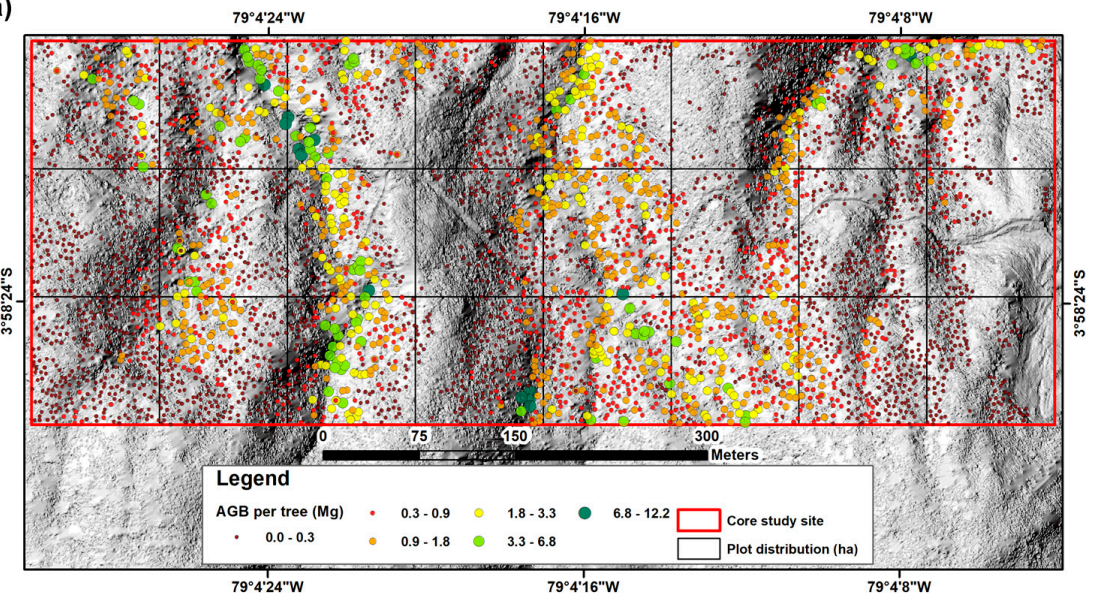

b) $79^{\circ} 4^{\prime} 24 " \mathrm{~W}$ $79^{\circ} 4^{\prime} 16^{\prime \prime} \mathrm{W}$ $79^{\circ} 4^{\prime} 8^{\prime \prime W}$

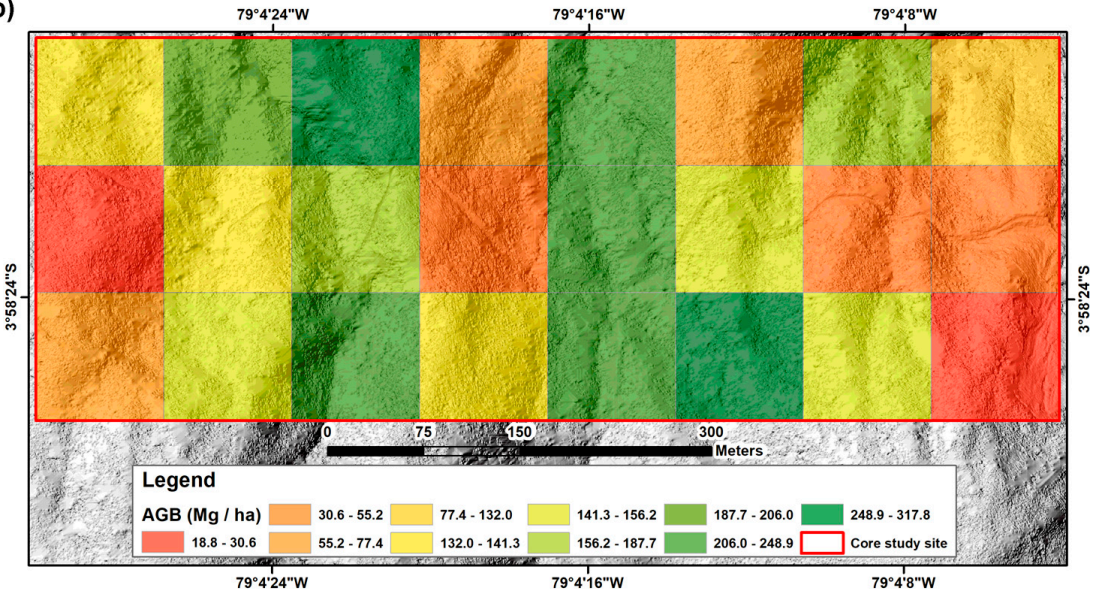

Figure 6. (a) Individual AGB values of the dominant trees detected in the core area; (b) Spatial distribution of AGB obtained from the RGB data.

$\mathrm{H}$ varied between $8.50 \mathrm{~m}$ to $35.32 \mathrm{~m}$ in the core area in which the individual tree distribution depended on the topographical position. Bigger trees were found in depressions (ravine forest) because these locations are topographically more protected compared to the ridges (ridge forest), and trees are generally taller there $[22,88]$. This is also caused by the prevailing soil types present at the different locations [53]. In general, the down-slope fluxes accumulate material and nutrients in the depression [22], which is why soil depth and nutrient concentrations are generally higher there, supporting the resulting tree growth $[22,88]$. The ridge forest parts are frequently affected by soil 
erosion processes due to the steeper slopes and harsher climate conditions [56], which lead to shallow soils and unstable conditions (landslides) at these areas [55], subsequently reducing tree growth.

The DBH ranged between $10.01 \mathrm{~cm}$ and $127.39 \mathrm{~cm}$, while distribution also depended on the topographical positions [54]. In general, the estimated AGB $\left(\mathrm{Mg} \mathrm{ha}^{-1}\right)$ was related to the topographical position and the specific forest type (ravine or ridge) and ranged between $18.77 \mathrm{Mg} \mathrm{ha}^{-1}$ (open ridge forest) and $317.77 \mathrm{Mg} \mathrm{ha}^{-1}$ (dense ravine forest), with a mean value of $148.83 \mathrm{Mg} \mathrm{ha}^{-1}$ for the core study area. In Figure 6, the aforementioned distribution is clearly visible, where higher AGB values (green and yellow colors) are located inside the side valley and near the valley bottom, whereas lower AGB values (orange and red colors) are displayed at the ridges or steep slopes, where small vegetation (shrubs or small trees) or regeneration areas prevail.

\subsection{AGB Results by Means of Multispectral Data}

By utilizing the multispectral data, a false color composite was generated as well as the individual NDVI values for each pixel $(25 \mathrm{~cm})$ calculated. The false color composite provided the basis for an unsupervised classification to divide the vegetation cover in herbs/bare soil, scrubland, and forest (Figure 7a). The vegetation classification was used for visual inspection to verify the calculated NDVI values corresponding to these vegetation classes. The calculated NDVI map is illustrated in Figure $7 \mathrm{~b}$, displaying generally high values of between 0.38 and 0.86 . Only water bodies (river course) showed negative values, while bare soil's NDVIs up to 0.20 . The remaining land cover units had high positive values, which indicates vigorous vegetation $[40,89]$. Nonetheless, the forest distribution is detectable in the NDVI map, where higher values (dark green) were displayed inside the side valleys and slightly lower values (light green) at the ridges (Figure $7 \mathrm{~b}$ ). The individual NDVI values were averaged for each hectare and integrated in Equation (4) to obtain AGB $\left(\mathrm{Mg} \mathrm{ha}^{-1}\right)$.

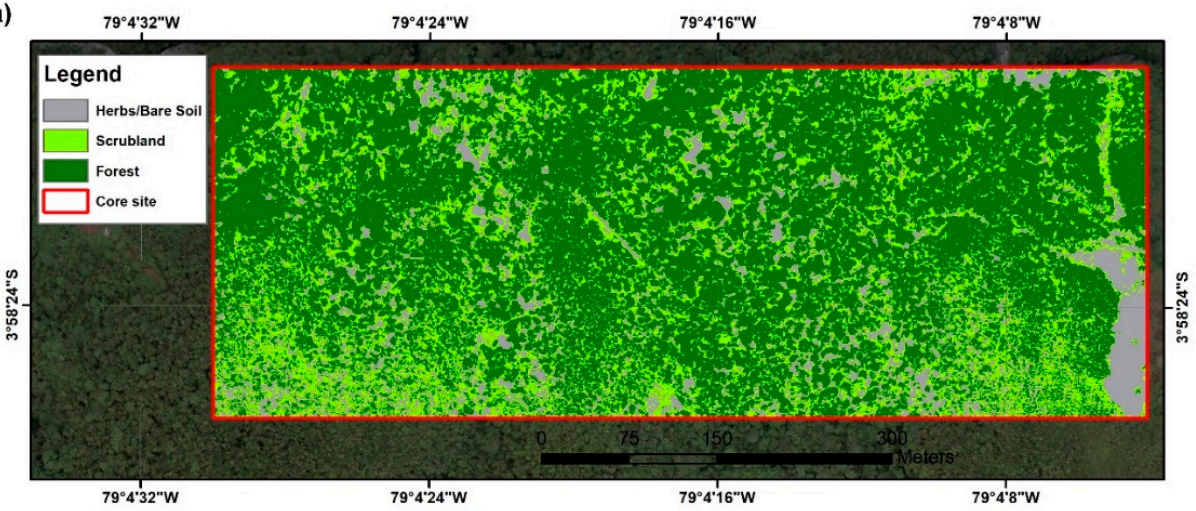

b)

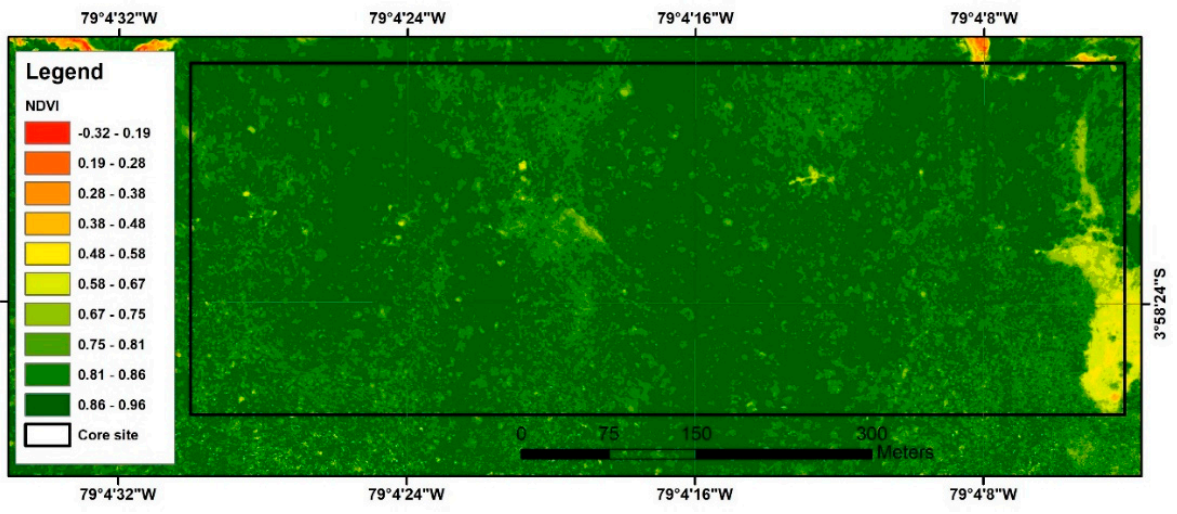

Figure 7. Multispectral data obtained by the multispectral camera, (a) non-supervised classification based on the false color composition image and (b) NDVI values. 
The resulting AGB map is illustrated in Figure 8, indicating values between 191.46 MG ha ${ }^{-1}$ and $252.11 \mathrm{Mg} \mathrm{ha}^{-1}$. The mean value corresponds to $237.21 \mathrm{Mg} \mathrm{ha}^{-1}$. However, due to the generally high NDVI in the study area (natural TMF), the differences between ravine and ridge forest were indistinct, which resulted in high AGB values for the whole area.

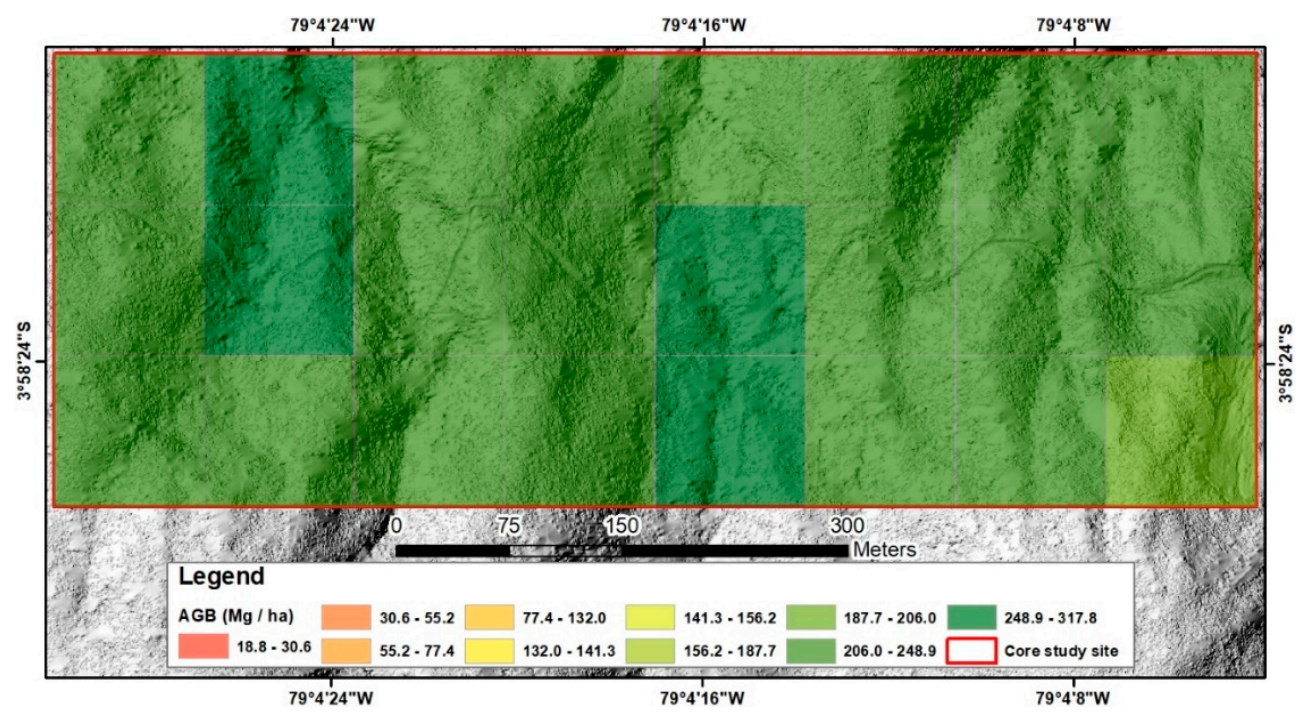

Figure 8. AGB estimation by means of multispectral data.

\subsection{Validation}

The validation was realized by means of the statistic software R-Studio (version 1.1.453) [90]. First, the results obtained from the RGB camera were analyzed, in which the individual generated models (DTM, DSM, and CHM) were compared to the LiDAR models [8]. The DTM comparison was made for two transects (Figure 3, yellow lines), one over dense vegetation cover and another over sparse or non-vegetation sites (Figure 9, red and black lines). It is clearly visible in Figure 9a that the RGB camera can hardly detect the terrain surface under dense vegetation (differences up to $20 \mathrm{~m}$ ) because this passive sensor is not able to penetrate dense canopy layers [91,92]. In contrast, for sparse or non-vegetated areas (Figure 9b), only small differences between the RGB-DTM and the LiDAR-DTM were obtained (differences up to $2 \mathrm{~m}$ ). Therefore, the RGB-DTM generation is largely inaccurate for natural tropical forests, especially for areas with dense vegetation, where high canopies obstruct the detection of the terrain surface (RGB-DTM RMSE: $\sim 9 \mathrm{~m}$, Table 1).

In contrast, the DSM comparison for both transects showed good accordance between the RGB and the LiDAR model because the top of the surface (here: Crown level) can be analyzed by means of RGB data (Figure 9, green and grey lines). This is confirmed by the statistics (Table 1), which determined a coefficient of determination $\left(R^{2}\right)$ of 0.99 with an RMSE of $3.05 \mathrm{~m}$ at very high significance level $<0.001$ ( $p$-value). However, differences between dense vegetation (Figure $9 a, R^{2}$ of 0.98 and a RMSE of $1.38 \mathrm{~m}$ ) and less-vegetated sites (Figure $9 \mathrm{~b}, \mathrm{R}^{2}$ of 0.99 with an RMSE of $0.49 \mathrm{~m}$ ) were notable, which is due to the irregular canopy layer in dense natural TMF [22] and the time span between the LiDAR and UAV survey (vegetation growth). 

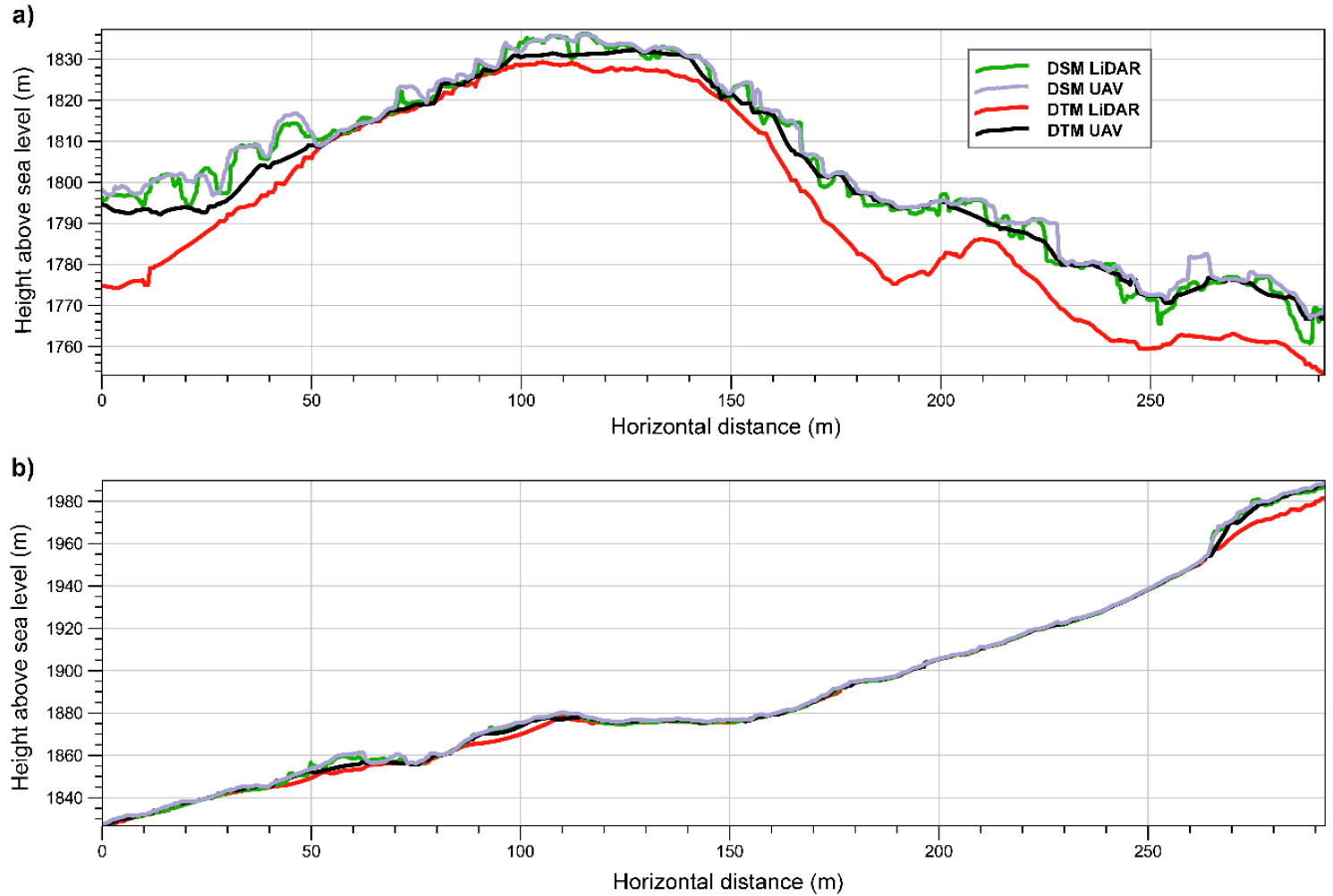

Figure 9. Transect profiles, comparing RGB and light detection and ranging (LiDAR) models: (a) Vegetated areas, (b) less vegetated areas.

By means of the DTM and the DSM, a CHM could be generated, but due to the high errors in the RGB-DTM, the RGB-CHM error also showed high inaccuracy (RMSE $=8.65 \mathrm{~m}$ ), and no correlation between RGB-CHM and LiDAR-CHM could be determined $\left(\mathrm{R}^{2}=0.18\right.$, Table 1$)$. Therefore, as Karpina et al. [77] suggested, the RGB-DTM was replaced by an accurate DTM in very high resolution (LiDAR-DTM) to guarantee a reliable CHM generation and a subsequent individual tree classification. Using the LiDAR-DTM in combination with the RGB-DSM (RGB-CHM*, Table 1), errors were notably reduced (RMSE $=3.00 \mathrm{~m}$ ) and a good correlation between the models was obtained $\left(R^{2}=0.80\right)$. Therefore, the RGB-CHM* model was used for the individual tree classification to determine $\mathrm{H}$ and $\mathrm{DBH}$ for the final AGB estimation.

Table 1. AGB validation comparing RGB models with the LiDAR models.

\begin{tabular}{cccc}
\hline Approach & $\mathbf{R}^{\mathbf{2}}$ & RMSE (m) & $p$-Value \\
\hline $\begin{array}{c}\text { RGB-DTM vs. } \\
\text { LiDAR-DTM }\end{array}$ & 0.99 & 8.95 & $<0.001$ \\
$\begin{array}{l}\text { RGB-DSM vs. } \\
\text { LiDAR-DSM }\end{array}$ & 0.99 & 3.05 & $<0.001$ \\
$\begin{array}{l}\text { RGB-CHM vs. } \\
\text { LiDAR-CHM }\end{array}$ & 0.18 & 8.65 & $<0.001$ \\
$\begin{array}{c}\text { RGB-CHM* vs. } \\
\text { LiDAR-CHM }\end{array}$ & 0.80 & 3.00 & $<0.001$ \\
\hline \multicolumn{4}{c}{$*$ combination of LiDAR-DTM and RGB-DSM. }
\end{tabular}

Within the core study area, a total of 7075 dominant trees were detected on basis of the RGB-CHM*, applying the canopy maxima method [80]. In comparison to the LiDAR-CHM in which 7317 trees were detected for the same area, results were similar (96.69\%, Table 2). From the individual tree detection, $\mathrm{H}$ was deviated and DBH of each tree calculated. As shown in Table 2, H and DBH values for the individual trees were in the same range comparing RGB and LiDAR data, which resulted in similar 
AGB values. However, maximum AGB values were slightly higher for the RGB data, which may be due to the RMSE of the RGB-DSM (Table 1) or the time span between the surveys (vegetation growth).

Table 2. Calculated H, DBH, and AGB values (RGB above and LiDAR below).

\begin{tabular}{|c|c|c|c|c|c|c|c|c|c|c|c|}
\hline \multirow{2}{*}{ Sensor } & \multirow{2}{*}{$\begin{array}{c}\text { Tree } \\
\text { Individuals }\end{array}$} & \multicolumn{3}{|c|}{ Height (m) } & \multicolumn{3}{|c|}{ DBH (cm) } & \multicolumn{4}{|c|}{ AGB (Mg/ha) } \\
\hline & & Min & Mean & $\operatorname{Max}$ & Min & Mean & Max & Min & Mean & Max & SD \\
\hline RGB & 7075 & 8.50 & 14.66 & 35.32 & 10.01 & 28.08 & 127.39 & 18.77 & 148.66 & 317.77 & 83.96 \\
\hline LiDAR & 7317 & 8.50 & 14.52 & 36.31 & 10.01 & 27.57 & 133.83 & 10.01 & 144.83 & 291.58 & 85.45 \\
\hline
\end{tabular}

Furthermore, the RGB results $(\mathrm{H}, \mathrm{DBH}$, and $\mathrm{AGB})$ were plotted against the LiDAR results (Figure 10). Therefore, the deviated $\mathrm{H}$ (Figure 10a) and calculated DBH values of all detected trees from the RGB (7075 individuals) were used and a linear regression analysis executed. The results showed a good correlation for $H\left(R^{2}=0.83\right)$ and DBH $\left(R^{2}=0.83\right)$. AGB amounts of the specific hectares (24 ha) were also compared, which resulted in a good correlation between RGB-AGB and LiDAR-AGB $\left(R^{2}=0.85\right.$, at a significance level $p$-value $<0.001$, Figure $\left.10 b\right)$.

a)

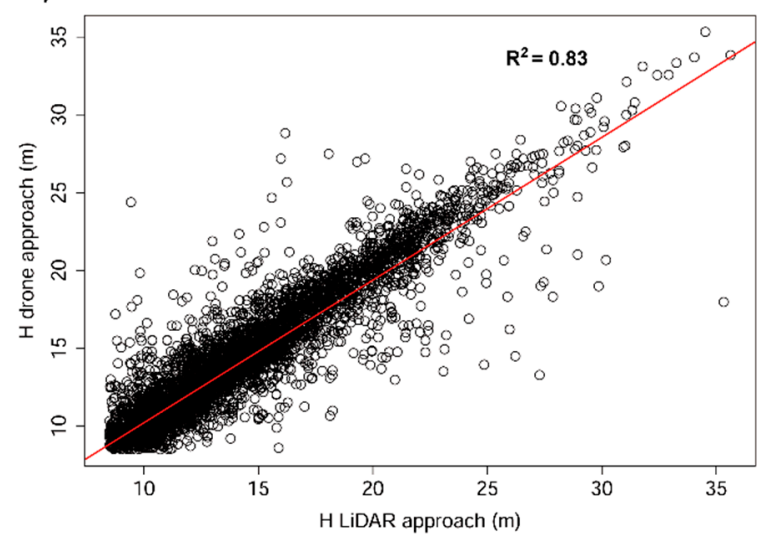

b)

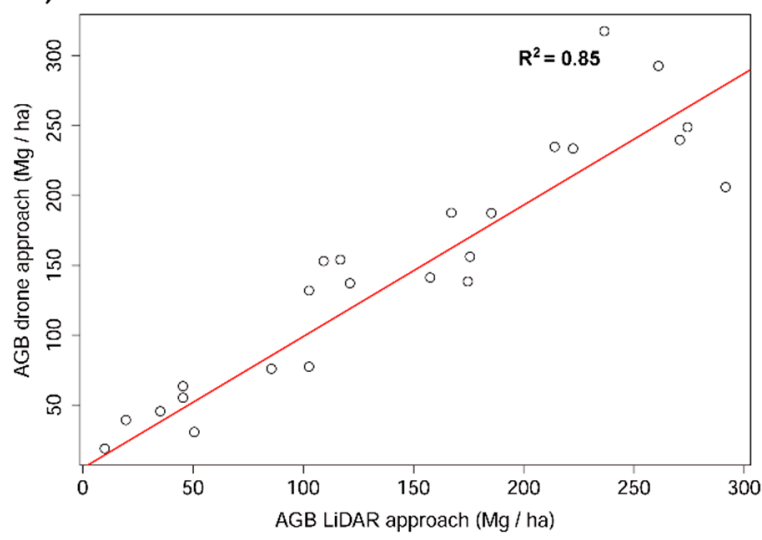

Figure 10. Regression analysis between RGB and LiDAR data: (a) H correlation, (b) AGB correlation.

Then, the AGB results obtained from the multispectral data were validated against the LiDAR estimates. In Table 3, the calculated minimum, mean, and maximum AGB values are presented, which indicate notable differences. The calculated minimum AGB of the multispectral data $\left(191.46 \mathrm{Mg} \mathrm{ha}^{-1}\right)$ was notably higher, whereas as maximum AGB $\left(252.11 \mathrm{Mg} \mathrm{ha}^{-1}\right)$ was lower than the LiDAR estimates. The absence of correlation between the multispectral and LiDAR results ( $p$-value $>0.05$ ) was confirmed by the very low $R^{2}(p$-value $<0.01)$ and the very high RMSE $(127.35 \mathrm{~m})$. The large differences were due to the tendency towards saturation of multispectral sensors for healthy and vigorous vegetation [82], for which reason, generally, high NDVI values were obtained for the whole area (Figure 7b), which resulted in similar AGB values for all hectares under study and consequently in unclear forest structure detection.

Table 3. Calculated AGB from multispectral and LiDAR data.

\begin{tabular}{cccccc}
\hline \multirow{2}{*}{ Sensor } & \multirow{2}{*}{ Cover (ha) } & \multicolumn{4}{c}{ AGB (Mg/ha) } \\
\cline { 3 - 6 } & & Min & Mean & Max & SD \\
\hline Multispectral & 24 & 191.46 & 237.21 & 252.11 & 13.02 \\
LiDAR & 24 & 10.01 & 144.83 & 291.58 & 85.45 \\
\hline
\end{tabular}




\section{Discussion}

Regarding the UAV technology used for AGB estimation in this natural TMF in Southern Ecuador, two main issues could be identified. First, flight time and image resolution are related to topographic conditions as well as to the payload capacity of the employed UAV, which determine the area covered by one single flight as well as the final GSD resolution (pixel size). Furthermore, a high overlap of the individual images is necessary and an adequate number of GCPs must be established $[67,68]$ to obtain the required image accuracy during the photogrammetric process. The second issue refers particularly to the RGB images and the 3D point cloud generation. As the study showed, terrain or ground data (DTM) under dense forest canopies cannot be detected accurately because passive sensors do not have the capacity to penetrate dense forest canopies [91,92]. However, the methodology can be applied in managed forest, where gaps are big enough and generally homogeneous, which permits the detection of the terrain [93]. In dense natural forest, an adequate auxiliary DTM in high resolution (here: LiDAR-DTM) is necessary to generate a realistic CHM for further analysis [77,94].

Considering the second issue, it could be stated that from the RGB-CHM ${ }^{*}$ the structural parameters of the forest could be identified, which include the forest type (here: Ravine or ridge) as well as $\mathrm{H}$ of each individual tree detected. Biggest trees were found in the protected ravine TMF parts (valleys and side valleys) with $\mathrm{H}$ up to $35.32 \mathrm{~m}$, similar to González-Jaramillo et al. [8], who used LiDAR data for individual tree classification $(36.31 \mathrm{~m}$, Table 1$)$. The same maximum $\mathrm{H}$ was reported by Paulick et al. [54] and Leuschner et al. [95] within the same study area. Besides this, mean H (14.66 m) was equal to the values presented by of Homeier et al. [96], who installed field plots at lower elevation, which confirms the accuracy of the applied method.

By means of the individual $\mathrm{H}$ and the specific equation proposed by González-Jaramillo et al. [8] for the San Francisco catchment, DBH was calculated at tree level. Due to similar H values (Figure 10a), a good correlation for DBH between RGB and LiDAR data could be recorded $\left(R^{2}: 0.83, p\right.$-value $<0.001$, Figure 10b). Mean DBH was only slightly higher $(28.08 \mathrm{~cm})$ than the validated values from the LiDAR data $(27.57 \mathrm{~cm}$, Table 1). However, other studies presented notably lower mean DBH for this TMF (Mean DBH: $9.8 \mathrm{~cm}$ ) [97], but these investigations included mid- and understory trees as well as trees at higher elevations, where harsher climate conditions and the more exposed position reduce $\mathrm{H}$ and DBH of the trees $[55,56]$.

The individual tree classification applied here only detects dominant trees because smaller mid- and understory trees are often not visible due to the upper canopy layer [78]. Therefore, RGB information, but also LiDAR approaches, slightly overestimate the real mean DBH in dense natural tropical forests [8]. Nonetheless, dominant trees are most important for AGB estimation because they represent $70 \%$ to $90 \%$ of the total AGB of a forest stand [18,19]. To calculate the AGB $\left(\mathrm{Mg} \mathrm{ha}^{-1}\right)$ by means of the individual tree classification, the specific allometric equation for wet forests from Chave et al. [49] was applied. The results clearly reflected the forest structure of this TMF because highest AGB was estimated inside the side valleys (ravine forest, up to $317.77 \mathrm{Mg} \mathrm{ha}^{-1}$ ), whereas lowest AGB was near the ridges (ridge forest, $18.77 \mathrm{Mg} \mathrm{ha}^{-1}$, Figure 6). Mean AGB for the core area (148.66 $\mathrm{Mg} \mathrm{ha}^{-1}$, Table 1) was in the same range as the LiDAR approach [8], but also similar to other AGB estimations published in previous studies $\left(150.0 \mathrm{Mg} \mathrm{ha}^{-1}\right)$ based on field plot measurements at lower elevation $[22,54,95,98]$. The small AGB differences between RGB-AGB and LiDAR-AGB were due to the RMSE of the RGB-CHM* and the number of trees detected, considering also the time span between RGB and LiDAR survey (see Section 4.3). Also of note, the TMF in the study area is protected and consists of mature forest (60 to 80 years old trees), where trees generally grow slowly, especially the older individuals [88]. Therefore, bigger AGB increments over time could not be expected, but other land cover changes, like landslides, which occur naturally, provoke a reduction in AGB for the affected areas until natural regeneration reestablishes the vegetation cover.

The multispectral image approach to calculate AGB by means of the deviated NDVI and applying the equation from Das and Singh [50] resulted in marked overestimations, especially for less vegetated sites (Table 3). This was principally due to the tendency towards saturation of the spectral bands 
over dense forest covers [82], resulting in similar and high AGB values for all hectares, which is why forest structure could not be depicted. This type of sensor saturation was also reported by Gu et al. [99], who obtained very high NDVI values in areas with dense canopies in the USA. Therefore, the NDVI can hardly be used in natural TMF for AGB estimation because differences in the fast-changing topography and vegetation cover cannot be detected. The applied equation from Das and Singh [50], who established their NDVI-AGB relationship in an evergreen forest in the Western Ghat region of India, also might not be suitable for AGB estimation in this TMF in Southern Ecuador. Therefore, the equation should be adjusted to provide explicit and more accurate NDVI-AGB relationships for individual ecosystems, but the matter with spectral band saturation for dense forest stand will persist. Nonetheless, the multispectral approach might be useful for crops in combination with crop height information to calculate the AGB $[46,100]$ due to the generally more uniform ground cover and topography.

In summary, the more effective and accurate approach to estimate AGB by means of UAVs in natural TMF is the RGB alternative, applying an analysis at tree level. During the process, forest structure as well as individual $\mathrm{H}$ and DBH of each tree detected can be determined [101]. These parameters, in combination with mean WD of the specific forest type, allowed a realistic AGB calculation. The RGB data permit the precise detection of the surface (DSM), but ancillary terrain data in high resolution (DTM) from other sources is necessary in natural tropical forest because the dense canopies impede ground detection (canopy closure often 100\%) [39,58]. However, in natural mid and high latitude forests [102] as well as in managed forests [93], the RGB approach might be a cost-effective alternative to expensive LiDAR surveys [103] due to the different forest stand characteristics with open canopies or regular distance between individual trees, which allows for accurate ground detection [77].

\section{Conclusions}

UAVs have the potential to generate terrain and surface information in high temporal and spatial resolution, due to their portability and flexibility. Furthermore, UAVs can be equipped with different sensors, which allow a wide range of applications and contribute to the advances in the remote sensing field. In contrast to classical remote sensing data (satellite images), UAVs also avoid the problems of cloudiness, which is particularly advantageous in tropical high mountains. Nonetheless, their range is limited due to the battery capacity and the additional payload, which reduce their flight time. Therefore, UAVs can adequately monitor smaller areas, besides the ability to fill gaps in existing imagery (e.g., LiDAR data).

As the study showed, for a reliable AGB estimation $\left(\mathrm{Mg} \mathrm{ha}^{-1}\right)$ in natural TMF, a tree level classification is necessary. This can be reached by RGB images with high side and forward overlap ( $80 \%$ or higher), to obtain multiple viewing angles of the objects to generate $3 \mathrm{D}$ point clouds. However, in natural tropical forests, terrain information is difficult to capture with this passive sensor due to the dense canopy layer, which impedes ground detection. Therefore, auxiliary DTMs in high resolution must be considered to generate reliable CHMs for the subsequent classification at tree level and AGB calculation.

In contrast, multispectral images suffer saturation of the spectral bands over dense natural forest stands, which results in generally high NDVI values with small differences between the land cover units. Therefore, AGB estimation, based on NDVI values, overestimates the real amounts in natural TMF, especially at less vegetated sites.

Author Contributions: V.G.-J. processed the UAV data, wrote and edited the manuscript. A.F. gave advice on the research design, analyzed the tree data and wrote the draft of the manuscript. J.B. gave advice on the research design and the methodology and also revised the manuscript.

Funding: This research was funded by DFG Research Unit 816: Biodiversity and Sustainable Management of Mega-diverse Mountain Ecosystems in South Ecuador (ALS under BE1780/17-2) and the APC was funded by Bilateral Cooperation with South Ecuadorian Universities in Ecosystem Research (BE1780-20-2; 27-2; 32-1). 
Acknowledgments: This study was executed in framework with the DFG Research Unit 816: Biodiversity and Sustainable Management of Mega-diverse Mountain Ecosystems in South Ecuador (ALS under BE1780/17-2). The authors thank the German Research Foundation DFG for funding the PhD of V. González-Jaramillo in the scope of the program "Bilateral Cooperation with South Ecuadorian Universities in Ecosystem Research" (BE1780-20-2; 27-2; 32-1). Thanks, are also due to the collaboration of the Universidad Técnica Particular de Loja (UTPL) to facilitate this research by means of project PY1760, funded by the Smart Land initiative. Special thanks to Gregory Gedeon for text revision.

Conflicts of Interest: The authors declare no conflict of interest.

\section{References}

1. Iizuka, K.; Yonehara, T.; Itoh, M.; Kosugi, Y. Estimating Tree Height and Diameter at Breast Height (DBH) from Digital Surface Models and Orthophotos Obtained with an Unmanned Aerial System for a Japanese Cypress (Chamaecyparis obtusa). For. Remote Sens. 2018, 10, 13. [CrossRef]

2. Shin, P.; Sankey, T.; Moore, M.M.; Thode, A.E. Evaluating Unmanned Aerial Vehicle Images for Estimating Forest Canopy Fuels in a Ponderosa Pine Stand. Remote Sens. 2018, 10, 1266. [CrossRef]

3. IPCC. Working Group I Contribution to the IPCC Fifth Assessment Report Climate Change 2013: The Physical Science Basics; IPCC: Stockholm, Sweden, 2013.

4. Pütz, S.; Groeneveld, J.; Henle, K.; Camargo Martensen, A.; Metz, M.; Metzger, J.P.; Ribeiro, M.C.; Dantas de Paula, M.; Huth, A. Long-term carbon loss in fragmented Neotropical forests. Nat. Commun. 2014, 5, 5037. [CrossRef]

5. Ota, T.; Kajisa, T.; Mizoue, N.; Yoshida, S.; Takao, G.; Hirata, Y.; Furuya, N.; Sano, T.; Ponce-Hernandez, R.; Ahmed, O.S.; et al. Estimating aboveground carbon using airborne LiDAR in Cambodian tropical seasonal forests for REDD+ implementation. J. For. Res. 2015, 20, 484-492. [CrossRef]

6. Mitchell, A.L.; Rosenqvist, A.; Mora, B. Current remote sensing approaches to monitoring forest degradation in support of countries measurement, reporting and verification (MRV) systems for REDD+. Carbon Balance Manag. 2017, 12, 9. [CrossRef]

7. FAO. Evaluación de Recursos Forestales Mundiales 2010_Informe Principal; FAO: Roma, Italy, 2010.

8. González-Jaramillo, V.; Fries, A.; Zeilinger, J.; Homeier, J.; Paladines-Benitez, J.; Bendix, J. Estimation of Above Ground Biomass in a Tropical Mountain Forest in Southern Ecuador Using Airborne LiDAR Data. Remote Sens. 2018, 10, 660. [CrossRef]

9. Tapia-Armijos, M.F.; Homeier, J.; Espinosa, C.I.; Leuschner, C.; de la Cruz, M. Deforestation and Forest Fragmentation in South Ecuador since the 1970s-Losing a Hotspot of Biodiversity. PLoS ONE 2015, 10, e0133701. [CrossRef]

10. FAO. Evaluación de los Recursos Forestales Mundiales 2010_Informe Nacional Ecuador; FAO: Roma, Italy, 2010.

11. Ochoa-Cueva, P.; Fries, A.; Montesinos, P.; Rodríguez-Díaz, J.A.; Boll, J. Spatial Estimation of Soil Erosion Risk by Land-cover Change in the Andes of Southern Ecuador. Land Degrad. Dev. 2015, 26, 565-573. [CrossRef]

12. Curatola Fernández, G.; Obermeier, W.; Gerique, A.; López Sandoval, M.; Lehnert, L.; Thies, B.; Bendix, J. Land cover change in the Andes of Southern Ecuador-Patterns and drivers. Remote Sens. 2015, 7, 2509-2542. [CrossRef]

13. Mosandl, R.; Günter, S.; Stimm, B.; Weber, M. Ecuador suffers the highest deforestation rate in South America. In Gradients in a Tropical Mountain Ecosystem of Ecuador, 1st ed.; Beck, E., Bendix, J., Kottke, I., Makeschin, F., Mosandl, R., Eds.; Ecological Studies; Springer: Berlin/Heidelberg, Germany, 2008; Volume 198, pp. 37-40.

14. Richter, M.; Beck, E.; Rollenbeck, R.; Bendix, J. The Study Area. In Ecosystem Services, Biodiversity and Environmental Change in a Tropical Mountain Ecosystem of South Ecuador, 1st ed.; Bendix, J., Beck, E., Bräuning, A., Makeschin, F., Mosandl, R., Scheu, S., Wilcke, W., Eds.; Springer: Berlin/Heidelberg, Germany, 2013; Volume 221, pp. 1-19, ISBN 978-3-642-38136-2.

15. Beck, E.; Harting, K.; Roos, K. Forest clearing by slash and burn. In Gradients in a Tropical Mountain Ecosystem of Ecuador, 1st ed.; Beck, E., Bendix, J., Kottke, I., Makeschin, F., Mosandl, R., Eds.; Ecological Studies; Springer: Berlin/Heidelberg, Germany, 2008; Volume 198, pp. 371-374.

16. Miettinen, J.; Stibig, H.-J.; Achard, F. Remote sensing of forest degradation in Southeast Asia-Aiming for a regional view through 5-30 m satellite data. Glob. Ecol. Conserv. 2014, 2, 24-36. [CrossRef]

17. Ortiz-Colín, P.; Toledo-Aceves, T.; López-Barrera, F.; Gerez-Fernández, P. Can traditional selective logging secure tree regeneration in cloud forest. iForest 2017, 10, 369-375. [CrossRef] 
18. Kotowska, M.M.; Leuschner, C.; Triadiati, T.; Meriem, S.; Hertel, D. Quantifying above- and belowground biomass carbon loss with forest conversion in tropical lowlands of Sumatra (Indonesia). Glob. Chang. Biol. 2015, 21, 3620-3634. [CrossRef] [PubMed]

19. Bastin, J.F.; Barbier, N.; Réjou-Méchain, M.; Fayolle, A.; Gourlet-Fleury, S.; Maniatis, D.; de Haulleville, T.; Baya, F.; Beeckman, H.; Beina, D. Seeing Central African forests through their largest trees. Sci. Rep. 2015, 5, 13156. [CrossRef] [PubMed]

20. Meyer, V.; Saatchi, S.; Clark, D.B.; Keller, M.; Vincent, G.; Ferraz, A.; Espírito-Santo, F.; d'Oliveira, M.V.N.; Kaki, D.; Chave, J. Canopy area of large trees explains aboveground biomass variations across neotropical forest landscapes. Biogeosciences 2018, 15, 3377-3390. [CrossRef]

21. Cuni-Sanchez, A.; Pfeifer, M.; Marchant, R.; Calders, K.; Sørensen, C.L.; Pompeu, P.V.; Lewis, S.L.; Burgess, N.D. New insights on above ground biomass and forest attributes in tropical montane forests. For. Ecol. Manag. 2017, 399, 235-246. [CrossRef]

22. Werner, F.A.; Homeier, J. Is tropical montane forest heterogeneity promoted by a resource-driven feedback cycle? Evidence from nutrient relations, herbivory and litter decomposition along a topographical gradient. Funct. Ecol. 2015, 29, 430-440. [CrossRef]

23. Ferraz, A.; Saatchi, S.; Mallet, C.; Jacquemoud, S.; Goncalves, G.; Silva, A.A.; Soares, P.; Tomé, M.; Pereira, L. Airbone Lidar Estimation of Aboveground Forest Biomass in the Absence of Field Inventory. Remote Sens. 2016, 8, 653. [CrossRef]

24. Sinha, S.; Jeganathan, C.; Sharma, L.K.; Nathawat, M.S. A review of radar remote sensing for biomass estimation. Int. J. Environ. Sci. Technol. 2015, 12, 1779-1792. [CrossRef]

25. Qin, Y.; Xiao, X.; Wang, J.; Dong, J.; Ewing, K.; Hoagland, B.; Hough, D.J.; Fagin, T.D.; Zou, Z.; Geissler, G.L.; et al. Mapping annual forest cover in sub-humid and semi-arid regions through analysis of Landsat and PALSAR imagery. Remote Sens. 2016, 8, 933. [CrossRef]

26. Galidaki, G.; Zianis, D.; Gitas, I.; Radoglou, K.; Karathanassi, V.; Tsakiri-Strati, M.; Woodhouse, I.; Mallinis, G. Vegetation biomass estimation with remote sensing: Focus on forest and other wooded land over the Mediterranean ecosystem. Int. J. Remote Sens. 2017, 38, 1940-1966. [CrossRef]

27. MacLachlan, A.; Roberts, G.; Biggs, E.; Boruff, B. Subpixel land-cover classification for improved urban area estimates using Landsat. Int. J. Remote Sens. 2017, 38, 5763-5792. [CrossRef]

28. Aasen, H.; Honkavaara, E.; Lucieer, A.; Zarco-Tejada, P.J. Quantitative Remote Sensing at Ultra-High Resolution with UAV Spectroscopy: A Review of Sensor Technology, Measurement Procedures, and Data Correction Workflows. Remote Sens. 2018, 10, 1091. [CrossRef]

29. Dash, J.P.; Pearse, G.D.; Watt, M.S. UAV Multispectral Imagery Can Complement Satellite Data for Monitoring Forest Health. Remote Sens. 2018, 10, 1216. [CrossRef]

30. Rodríguez-Veiga, P.; Wheeler, J.; Louis, V.; Tansey, K.; Balzter, H. Quantifying forest biomass carbon stocks from space. Curr. For. Rep. 2017, 3, 1-18. [CrossRef]

31. Silva, B.; Bendix, J. Remote sensing of vegetation in a tropical mountain ecosystem: Individual tree-crown detection. Proc. SPIE 2013, 8893, 99830B.

32. Asner, G.P.; Mascaro, J. Mapping tropical forest carbon: Calibrating plot estimates to a simple LiDAR metric. Remote Sens. Environ. 2014, 140, 614-624. [CrossRef]

33. Li, A.; Dhakal, S.; Glenn, N.F.; Spaete, L.P.; Shinneman, D.J.; Pilliod, D.S.; Arkle, R.S.; McIlroy, S.K. Lidar Aboveground Vegetation Biomass Estimates in Shrublands: Prediction, Uncertainties and Application to Coarser Scales. Remote Sens. 2017, 9, 903. [CrossRef]

34. Wallis, C.I.; Homeier, J.; Peña, J.; Brandl, R.; Farwig, N.; Bendix, J. Modeling tropical montane forest biomass, productivity and canopy traits with multispectral remote sensing data. Remote Sens. Environ. 2019, 225, 77-92. [CrossRef]

35. Bendix, J.; Rollenbeck, R.; Palacios, E. Cloud detection in the Tropics-A suitable tool for climate-ecological studies in the high mountains of Ecuador. Int. J. Remote Sens. 2004, 25, 4521-4540. [CrossRef]

36. Purnamasayangsukasih, R.P.; Norizah, K.; Ismail, A.A.M.; Shamsudin, I. A review of uses of satellite imagery in monitoring mangrove forests. IOP Conf. Ser. Earth Environ. Sci. 2016, 37, 012034. [CrossRef]

37. Zhang, X.; Friedl, M.A.; Schaaf, C.B.; Strahler, A.H.; Hodges, J.C.F.; Gao, F.; Reed, B.C.; Huete, A. Monitoring vegetation phenology using MODIS. Remote Sens. Environ. 2003, 84, 471-475. [CrossRef] 
38. Paruelo, J.M.; Garbulsky, M.F.; Guerschman, J.P.; Jobbágy, E.G. Two decades of Normalized Difference Vegetation Index changes in South America: Identifying the imprint of global change. Int. J. Remote Sens. 2004, 25, 2793-2806. [CrossRef]

39. Göttlicher, D.; Obregon, A.; Homeier, J.; Rollenbeck, R.; Nauss, T.; Bendix, J. Land-cover classification in the Andes of southern Ecuador using Landsat ETM+ data as a basis for SVAT modelling. Int. J. Remote Sens. 2009, 30, 1867-1886. [CrossRef]

40. González-Jaramillo, V.; Fries, A.; Rollenbeck, R.; Paladines, J.; Oñate-Valdivieso, F.; Bendix, J. Assessment of deforestation during the last decades in Ecuador using NOAA-AVHRR satellite data. Erdkunde 2016, 70, 217-235. [CrossRef]

41. Kim, E.; Lee, W.K.; Yoon, M.; Lee, J.Y.; Son, Y.; Abu Salim, K. Estimation of Voxel-Based Above-Ground Biomass Using Airborne LiDAR Data in an Intact Tropical Rain Forest, Brunei. Forests 2016, 7, 259. [CrossRef]

42. Candiago, S.; Remondino, F.; De Giglio, M.; Dubbini, M.; Gattelli, M. Evaluating Multispectral Images and Vegetation Indices for Precision Farming Applications from UAV Images. Remote Sens. 2015, 7, 4026-4047. [CrossRef]

43. Connor, D.; Martin, P.G.; Scott, T.B. Airborne radiation mapping: Overview and application of current and future aerial systems. Int. J. Remote Sens. 2016, 37, 5953-5987. [CrossRef]

44. Saarinen, N.; Vastaranta, M.; Näsi, R.; Rosnell, T.; Hakala, T.; Honkavaara, E.; Wulder, M.A.; Luoma, V.; Tommaselli, A.M.G.; Imai, N.N.; et al. Assessing Biodiversity in Boreal Forests with UAV-Based Photogrammetric Point Clouds and Hyperspectral Imaging. Remote Sens. 2018, 10, 338. [CrossRef]

45. Kachamba, D.J.; Ørka, H.O.; Gobakken, T.; Eid, T.; Mwase, W. Biomass Estimation Using 3D Data from Unmanned Aerial Vehicle Imagery in a Tropical Woodland. Remote Sens. 2016, 8, 968. [CrossRef]

46. Yue, J.; Yang, G.; Li, C.; Li, Z.; Wang, Y.; Feng, H.; Xu, B. Estimation of Winter Wheat Above-Ground Biomass Using Unmanned Aerial Vehicle-Based Snapshot Hyperspectral Sensor and Crop Height Improved Models. Remote Sens. 2017, 9, 708. [CrossRef]

47. Weber, A.; Lerch, T. Point Clouds: Lase Scanning versus UAS Photogrammetry. GIM Int. 2018, 4, 36-39.

48. DJI. Inspire 1 Specs. Available online: https://www.dji.com/inspire-1/info\#downloads (accessed on 10 October 2018).

49. Chave, J.; Andalo, C.; Brown, S.; Cairns, M.A.; Chambers, J.Q.; Eamus, D.; Fölster, H.; Fromard, F.; Higuchi, N.; Kira, T.; et al. Tree allometry and improved estimation of carbon stocks and balance in tropical forests. Oecologia 2005, 145, 87-99. [CrossRef] [PubMed]

50. Das, S.; Singh, T.P. Forest Type, Diversity and Biomass Estimation in Tropical Forests of Western Ghat of Maharashtra Using Geospatial Techniques. Small-Scale For. 2016, 15, 517. [CrossRef]

51. Homeier, J.; Werner, F.A.; Gradstein, S.R.; Breckle, S.-W.; Richter, M. Potential vegetation and floristic composition of Andean forests in South Ecuador, with a focus on the RBSF. In Gradients in a Tropical Mountain Ecosystem of Ecuador, 1st ed.; Beck, E., Bendix, J., Kottke, I., Makeschin, F., Mosandl, R., Eds.; Ecological Studies; Springer: Berlin/Heidelberg, Germany, 2008; Volume 198, pp. 87-100.

52. Bendix, J.; Beck, E. Spatial aspects of ecosystem research in a biodiversity hot spot of southern Ecuador-An introduction. Erdkunde 2009, 63, 305-308. [CrossRef]

53. Moser, G.; Leuschner, C.; Hertel, D.; Graefe, S.; Soethe, N.; Iost, S. Elevation effects on the carbon budget of tropical mountain forests (S Ecuador): The role of the belowground compartment. Glob. Chang. Biol. 2011, 17, 2211-2226. [CrossRef]

54. Paulick, S.; Dislich, C.; Homeier, J.; Fischer, R.; Huth, A. The carbon fluxes in different successional stages: Modelling the dynamics of tropical montane forests in South Ecuador. For. Ecosyst. 2017, 4, 5. [CrossRef]

55. Dislich, C.; Huth, A. Modelling the impact of shallow landslides on forest structure in tropical montane forests. Ecol. Model. 2012, 239, 40-53. [CrossRef]

56. Wagemann, J.; Thies, B.; Rollenbeck, R.; Peters, T.; Bendix, J. Regionalization of wind-speed data to analyze tree-line wind conditions in the eastern Andes of southern Ecuador. Erdkunde 2015, 69, 13-19. [CrossRef]

57. Fries, A.; Rollenbeck, R.; Göttlicher, D.; Nauß, T.; Homeier, J.; Peters, T.; Bendix, J. Thermal structure of a megadiverse Andean mountain ecosystem in southern Ecuador and its regionalization. Erdkunde 2009, 63, 321-335. [CrossRef]

58. Fries, A.; Rollenbeck, R.; Nauß, T.; Peters, T.; Bendix, J. Near surface air humidity in a megadiverse Andean mountain ecosystem of southern Ecuador and its regionalization. Agric. For. Meteorol. 2012, 152, 17-30. [CrossRef] 
59. Bendix, J.; Rollenbeck, R.; Richter, M.; Fabian, P.; Emck, P. Climate. In Gradients in a Tropical Mountain Ecosystem of Ecuador, 1st ed.; Beck, E., Bendix, J., Kottke, I., Makeschin, F., Mosandl, R., Eds.; Ecological Studies; Springer: Berlin/Heidelberg, Germany, 2008; Volume 198, pp. 63-74.

60. Fries, A.; Rollenbeck, R.; Bayer, F.; Gonzalez, V.; Oñate-Valivieso, F.; Peters, T.; Bendix, J. Catchment precipitation processes in the San Francisco valley in southern Ecuador: Combined approach using high-resolution radar images and in situ observations. Meteorol. Atmos. Phys. 2014, 126, 13-29. [CrossRef]

61. Windhorst, D.; Waltz, T.; Timbe, E.; Frede, H.G.; Breuer, L. Impact of elevation and weather patterns on the isotopic composition of precipitation in a tropical montane rainforest. Hydrol. Earth Syst. Sci. 2013, 17, 409-419. [CrossRef]

62. Parrot Sequoia. Available online: https://www.parrot.com/business-solutions-us/parrot-professional/parrotsequoia\#parrot-sequoia- (accessed on 5 October 2017).

63. AirInov-Parrot Sequoia Calibration Target. Available online: https://www.parrot.com/business-solutionsus/spareparts/business-solutions/parrot-sequoia-calibration-target (accessed on 5 October 2017).

64. PRECISIONFLIGHT FREE. Available online: https://www.precisionhawk.com/precisionflight (accessed on 5 October 2017).

65. Pix4D—Measure from Images. Available online: https://www.pix4d.com/ (accessed on 5 October 2017).

66. Sayab, M.; Aerden, D.; Paananen, M.; Saarela, P. Virtual Structural Analysis of Jokisivu Open Pit Using 'Structure-from-Motion' Unmanned Aerial Vehicles (UAV) Photogrammetry: Implications for Structurally-Controlled Gold Deposits in Southwest Finland. Remote Sens. 2018, 10, 1296. [CrossRef]

67. Claros, R.; Guevara, A.; Pacas, N. Aplicación de Fotogrametría Aérea en Levantamientos Topográficos mediante el uso de Vehículos Aéreos no Tripulados. Civil Engineer. Universidad de El Salvador: El Salvador, 2016. Available online: http://ri.ues.edu.sv/14218/1/50108282.pdf (accessed on 10 April 2019).

68. Boccardo, P.; Chiabrando, F.; Dutto, F.; Tonolo, F.G.; Lingua, A. UAV Deployment Exercise for Mapping Purposes: Evaluation of Emergency Response Applications. Sensors 2015, 15, 15717-15737. [CrossRef] [PubMed]

69. Chave, J.; Réjou-Méchain, M.; Búrquez, A.; Chidumayo, E.; Colgan, M.S.; Delitti, W.B.; Duque, A.; Eid, T.; Fearnside, P.M.; Goodman, R.C.; et al. Improved allometric models to estimate the aboveground biomass of tropical trees. Glob Chang. Biol. 2014, 20, 3177-3190. [CrossRef]

70. Piiroinen, R.; Heiskanen, J.; Maeda, E.; Viinikka, A.; Pellikka, P. Classification of tree species in a diverse African Agroforestry landscape using imaging spectroscopy and laser scanning. Remote Sens. 2017, 9, 875. [CrossRef]

71. Coomes, D.A.; Dalponte, M.; Jucker, T.; Asner, G.P.; Banin, L.F.; Burslem, D.F.R.P.; Lewis, S.L.; Nilus, R.; Phillips, O.L.; Phua, M.; et al. Area-based vs tree-centric approaches to mapping forest carbon in Southeast Asian forests from airborne laser scanning data. Remote Sens. Environ. 2017, 194, 77-88. [CrossRef]

72. Gao, X.; Li, Z.; Yu, H.; Jiang, Z.; Wang, C.; Zhang, Y.; Qi, L.; Shi, L. Modeling of the height-diameter relationship using an allometric equation model: A case study of stands of Phyllostachys edulis. J. For. Res. 2016, 27, 339-347. [CrossRef]

73. Urbazaev, M.; Thiel, C.; Cremer, F.; Dubayah, R.; Migliavacca, M.; Reichstein, M.; Schmullius, C. Estimation of forest aboveground biomass and uncertainties by integration of field measurements, airborne LiDAR, and SAR and optical satellite data in Mexico. Carbon Balance Manag. 2018, 13, 5. [CrossRef]

74. Wallace, L.; Lucieer, A.; Malenovský, Z.; Turner, D.; Vop`enka, P. Assessment of Forest Structure Using Two UAV Techniques: A Comparison of Airborne Laser Scanning and Structure from Motion (SfM) Point Clouds. Forests 2016, 7, 62. [CrossRef]

75. Burns, J.H.R.; Delparte, D. Comparison of commercial structure-from-motion photogrammety software used for underwater three-dimensional modeling of coral reef environments. Int. Arch. Photogramm. Remote Sens. 2017, XLII-2/W3, 127-131. [CrossRef]

76. Jiang, S.; Jiang, W. Efficient SfM for Oblique UAV Images: From Match Pair Selection to Geometrical Verification. Remote Sens. 2018, 10, 1246. [CrossRef]

77. Karpina, M.; Jarz,abek-Rychard, M.; Tymków, P.; Borkowski, A. UAV-Based Automatic Tree Growth Measurement for Biomass Estimation. ISPRS Int. Arch. Photogramm. Remote Sens. Spat. Inf. Sci. 2016, XLI-B8, 685-688. [CrossRef]

78. McGaughey, R.J. FUSION/LDV: Software for LIDAR Data Analysis and Visualization; version 3.70; United States Department of Agriculture, Forest Service: Washington, DC, USA, 2018. 
79. Gianico, V.; Lafortezza, R.; Jhon, R.; Sanesi, G.; Pesola, L.; Chen, J. Estimating Stand Volume and Above-Ground Biomass of Urban Forest Using LiDAR. Remote Sens. 2016, 8, 339. [CrossRef]

80. Shiota, H.; Tanaka, K.; Nagashima, K. LiDAR Data Analysis with Fusion/LDV for Individual Tree. J. Biodivers. Manag. For. 2017, 2017, 6. [CrossRef]

81. Homeier, J.; Werner, F.A.; Gawlik, J.; Peters, T.; Diertl, K.H.J.; Richter, M. Plant Diversity and its Relevance for the Provision of Ecosystem Services. In Ecosystem Services, Biodiversity and Environmental Change in a Tropical Mountain Ecosystem of South Ecuador, 1st ed.; Bendix, J., Beck, E., Bräuning, A., Makeschin, F., Mosandl, R., Scheu, S., Wilcke, W., Eds.; Springer: Berlin, Germany, 2013; Volume 221, pp. 100-118, ISBN 978-3-642-38136-2.

82. Zhao, P.; Lu, D.; Wang, G.; Wu, C.; Huang, Y.; Yu, S. Examining spectral reflectance saturation in Landsat imagery and corresponding solutions to improve forest aboveground biomass estimation. Remote Sens. 2016, 8, 469. [CrossRef]

83. Hillier, A. Working with ArcView 10; University of Pennsylvania: Philadelphia, PA, USA, 2011.

84. Ollado Latorre, J.; Navarro Jover, J.M. ArcGIS 10: Prácticas Paso a Paso; Universitat Politécnica: València, Spain, 2013.

85. Fensholt, R.; Rasmussen, K.; Nielsen, T.T.; Mbow, C. Evaluation of earth observation based long term vegetation trends - Intercomparing NDVI time series trend analysis consistency of Sahel from AVHRR GIMMS, Terra MODIS and SPOT VGT data. Remote Sens. Environ. 2009, 113, 1886-1898. [CrossRef]

86. Chuvieco, E. Teledetección Ambiental: La Observación de la Tierra desde el Espacio, 3rd ed.; Editorial Ariel: Barcelona, Spain, 2010.

87. Feng, Y.; Lu, D.; Chen, Q.; Keller, M.; Moran, E.; Nara dos-Santos, M.; Bolfe, E.L.; Batistella, M. Examining effective use of data sources and modeling algorithms for improving biomass estimation in a moist tropical forest of the Brazilian Amazon. Int. J. Digit. Earth 2017. [CrossRef]

88. Cabrera, O.; Fries, A.; Hildebrandt, P.; Günter, S.; Mosandl, R. Early Growth Response of Nine Timber Species to Release in a Tropical Mountain Forest of Southern Ecuador. Forests 2019, 10, 254. [CrossRef]

89. Weier, J.; Herring, D. Measuring Vegetation (NDVI \& EVI). 2000. Available online: https://earthobservatory. nasa.gov/features/MeasuringVegetation (accessed on 20 October 2018).

90. RStudio. Available online: https://www.r-studio.com/downloads/Recovery_Manual.pdf (accessed on 25 October 2018).

91. Mlambo, R.; Woodhouse, I.H.; Gerard, F.; Anderson, K. Structure from Motion (SfM) Photogrammetry with Drone Data: A Low Cost Method for Monitoring Greenhouse Gas Emissions from Forests in Developing Countries. Forests 2017, 8, 68. [CrossRef]

92. Nevalainen, O.; Honkavaara, E.; Tuominen, S.; Viljanen, N.; Hakala, T.; Yu, X.; Hyyppä, J.; Saari, H.; Pölönen, I.; Imai, N.N.; et al. Individual Tree Detection and Classification with UAV-Based Photogrammetric Point Clouds and Hyperspectral Imaging. Remote Sens. 2017, 9, 185. [CrossRef]

93. Getzin, S.; Nuske, R.S.; Wiegand, K. Using Unmanned Aerial Vehicles (UAV) to Quantify Spatial Gap Patterns in Forests. Remote Sens. 2014, 6, 6988-7004. [CrossRef]

94. Hsieh, Y.C.; Chan, Y.C.; Hu, J.C. Digital Elevation Model Differencing and Error Estimation from Multiple Sources: A Case Study from the Meiyuan Shan Landslide in Taiwan. Remote Sens. 2016, 8, 199. [CrossRef]

95. Leuschner, C.; Zach, A.; Moser, G.; Homeier, J.; Graefe, S.; Hertel, D.; Wittich, B.; Soethe, N.; Iost, S.; Röderstein, M.; et al. The Carbon Balance of Tropical Mountain Forests Along an Altitudinal Transect. In Ecosystem Services, Biodiversity and Environmental Change in a Tropical Mountain Ecosystem of South Ecuador, 1st ed.; Bendix, J., Beck, E., Bräuning, A., Makeschin, F., Mosandl, R., Scheu, S., Wilcke, W., Eds.; Springer: Berlin, Germany, 2013; Volume 221, pp. 117-139, ISBN 978-3-642-38136-2.

96. Homeier, J.; Breckle, S.-W.; Günter, S.; Rollenbeck, R.T.; Leuschner, C. Tree Diversity, Forest Structure and Productivity along Altitudinal and Topographical Gradients in a Species-Rich Ecuadorian Montane Rain Forest. Biotropica 2010, 42, 140-148. [CrossRef]

97. Leuschner, C.; Moser, G. Carbon Allocation and productivity in tropical mountain forest. In The Tropical Mountain Forest. Patterns and Process in a Biodiversity Hotspot; Biodiversity and Ecology Series; Gradstein, S.R., Homeier, J., Gansert, D., Eds.; Universitätsverlang Göttingen: Göttingen, Germany, 2008; Volume 2, pp. 109-128.

98. Dislich, C.; Günter, S.; Homeier, J.; Schröder, B.; Huth, A. Simulating forest dynamics of a tropical montane forest in South Ecuador. Erdkunde 2009, 63, 347-364. [CrossRef] 
99. Gu, Y.; Wylie, B.K.; Howard, D.M.; Phuyal, K.P.; Ji, L. NDVI saturation adjustment: A new approach for improving cropland performance estimates in the Greater Platte River Basin, USA. Ecol. Indic. 2013, 30, 1-6. [CrossRef]

100. Bendig, J.; Bolten, A.; Bennertz, S.; Broscheit, J.; Eichfuss, S.; Bareth, G. Estimating Biomass of Barley Using Crop Surface Models (CSMs) Derived from UAV-Based RGB Imaging. Remote Sens. 2014, 6, 10395-10412. [CrossRef]

101. Teobaldelli, M.; Cona, F.; Saulino, L.; Migliozzi, A.; D’Urso, G.; Langella, G.; Manna, P.; Saracino, A. Detection of diversity and stand parameters in Mediterranean forests using leaf-off discrete return LiDAR data. Remote Sens. Environ. 2017, 192, 126-138. [CrossRef]

102. Fritz, A.; Kattenborn, T.; Koch, B. Uav-Based Photogrammetric Point Clouds-Tree STEM Mapping in Open Stands in Comparison to Terrestrial Laser Scanner Point Clouds. Isprs Int. Arch. Photogramm. Remote Sens. Spat. Inf. Sci. 2013, XL-1/W2, 141-146. [CrossRef]

103. Li, W.; Niu, Z.; Chen, H.; Li, D.; Wu, M.; Zhao, W. Remote estimation of canopy height and aboveground biomass of maize using high-resolution stereo images from a low-cost unmanned aerial vehicle system. Ecol. Indic. 2016, 67, 637-648. [CrossRef]

(C) 2019 by the authors. Licensee MDPI, Basel, Switzerland. This article is an open access article distributed under the terms and conditions of the Creative Commons Attribution (CC BY) license (http://creativecommons.org/licenses/by/4.0/). 